\title{
COMMENTS
}

\section{A Poor Relation? Regulatory Takings after Dolan $v$ City of Tigard}

\author{
Daniel A. Crane†
}

The Takings Clause of the Fifth Amendment provides that no private property shall be taken for public use without just compensation. ${ }^{1}$ Although the Clause applies most obviously to the eminent domain power of the state, the Supreme Court has long recognized that certain land use regulations that stop short of physical appropriations by the government also fall within the ambit of the Takings Clause. ${ }^{2}$ The regulatory takings theory has produced substantial litigation between landowners seeking to improve or otherwise use their property, on the one hand, and government regulators seeking to promote such public goods as historical and environmental preservation and infrastructure improvements, on the other. ${ }^{3}$ In recent years, litigation has focused particularly on attempts by municipalities to condition approval of real estate development permits on landowners' dedicating portions of their property to public use, a practice known as "exaction."

$\dagger$ B.A. 1991, Wheaton College; J.D. Candidate 1996, The University of Chicago.

1 US Const, Amend V. The Takings Clause was incorporated against the states in Chicago, Burlington \& Quincy Railraad v City of Chicago, 166 US 226 (1896).

${ }^{2}$ See, for example, Pennsylvania Coal Co. v Mahon, 260 US 393, 415 (1922) (holding that a land use regulation becomes a taking when it "goes too far").

" See, for example, Pennsylvania Central Transportation Co. $v$ New York City, 438 US 104 (1978) (landowner challenging landmark preservation ordinance); Agins $v$ City of Tiburon, 447 US 255 (1980) (landowners challenging open-land zoning requirement); United States $v$ Riverside Bayview Homes, Inc., 474 US 121 (1985) (landowner challenging permit requirement for discharge of fill materials into private property).

4 See Donald L. Connors and Michael E. High, The Expanding Circle of Exactions: 
The present struggle over regulatory takings in general, and exactions in particular, is being played out on a vast constitutional stage, against a background that involves not only the Takings Clause, but also the Court's entire post-Lochner ${ }^{5}$ economic and property rights jurisprudence. Since the end of the Lochner era, demarked by United States $v$ Carolene Products Co., ${ }^{6}$ the Court has generally applied a low level of judicial scrutiny to substantive due process challenges ${ }^{7}$ to regulations affecting primarily economic interests. ${ }^{8}$ Subsequently, the Court extended this low level scrutiny beyond the economic substantive due process context to the Takings Clause context.9 Consistent with the outcomes of the post-Carolene Products substantive due process cases, the Court's regulatory takings jurisprudence has traditionally tended to tilt heavily in favor of the regulatory state. ${ }^{10}$

From Dedication to Linkage, $50 \mathrm{~L}$ \& Contemp Probs 69, 70 (1987). One commentator has noted that "[a] recent national survey indicates that eighty-eight percent of all communities in the United States require some exactions as a part of the development process." Emeline C. Acton, Much Ado About Nollan: The Supreme Court Addresses the Complex Network of Property Rights, Land Use Regulations, and Just Compensation in the Keystone, Nollan, and First English Cases, 17 Stetson L Rev 727, 749 (1988), citing Elizabeth D. Purdam and James E. Frank, Community Use of Exactions: Results of a National Survey, in James E. Frank and Robert M. Rhodes, eds, Development Exactions 126 (Planners 1986).

' Lochner v New York, 198 US 45 (1905). For cases repudiating Lochner's laissezfaire approach to the regulation of economic interests, see Nebbia $v$ New York, 291 US 502, 538-39 (1934) (upholding New York price-fixing statute against substantive due process challenge); West Coast Hotel Co. $v$ Parrish, 300 US 379, 400 (1937) (upholding statute regulating hours and working conditions of women against due process challenge); Williamson v Lee Optical Co., 348 US 483, 491 (1955) (holding that Oklahoma statute regulating opticians did not violate Due Process Clause); Ferguson v Skrupa, 372 US 726, 732 (1963) (rejecting due process challenge to Kansas statute limiting debt adjusting to lawyers).

6 304 US 144 (1938).

7 Substantive due process is the view "that the Due Process Clauses do require that deprivations of life, liberty, or property be substantively reasonable, i.e., that they be supported by some legitimate justification." Russell W. Galloway, Jr., Basic Substantive Due Process Analysis, 26 USF L Rev 625, 626 (1992).

${ }^{8}$ See, for example, Carolene Products, 304 US at 152-53. Notwithstanding this general rule, heightened scrutiny would be applied where regulations interfered with certain specifically enumerated rights, or the rights of "discrete and insular minorities." Id n 4.

9 In Goldblatt $v$ Town of Hempstead, 369 US 590, 594-96 (1962), the Supreme Court applied a reasonableness standard to a Takings Clause claim. The Court later rejected the application of this low level scrutiny in Nollan v California Coastal Commission, 483 US 825, 834-35 n 3 (1987).

${ }_{10}$ See, for example, the discussion of Mahon, 260 US 393, in notes 20-29 and accompanying text. A short list of the most significant decisions rejecting regulatory takings claims would include Village of Euclid v Ambler Realty Co., 272 US 365, 397 (1926) (upholding zoning ordinances); Miller $v$ Schoene, 276 US 272, 281 (1928) (upholding right of state to order removal of privately owned trees to prevent the spread of disease to other 
However, over the past eight years, the Rehnquist Court has begun to reinvigorate the Takings Clause, much to the joy of property rights activists and to the dismay of environmentalists and municipal regulators. In its most recent takings case, Dolan $v$ City of Tigard, the Court held that, when a municipality requires a landowner to dedicate a portion of his land to public use in exchange for development approval, a taking occurs unless the impact of the development is roughly proportional to the required dedication. ${ }^{11}$ In addition to announcing this new "rough proportionality" test, the Court noted in dictum that the Takings Clause should not be a "poor relation" to the First and Fourth Amendments-constitutional protections traditionally afforded a much more exacting standard of review than that applied to Takings Clause claims. ${ }^{12}$ This statement appears to reverse the settled presumption that, in the post-Carolene Products regime, property interests are "poor relations in the world of rights ...."13 Taken at face value, the poor relation dictum suggests that the level of scrutiny applied to all Takings Clause claims should be raised significantly.

Whether the poor relation dictum signals a coming constitutional revolution remains to be seen. This Comment does not address that question. ${ }^{14}$ Rather, it seeks to ascertain whether the Court acted upon its own suggestion and applied a heightened level of Takings Clause scrutiny in Dolan. To that end, this Comment confines itself to an analysis of the level of scrutiny

trees); Pennsylvania Central, 438 US at 138 (upholding municipal ordinance requiring owners of historical landmarks to maintain them in traditional form at their own expense); Pruneyard Shopping Center v Robins, 447 US 74, 88 (1980) (rejecting claim that state requirement that owners of shopping center allow petitioners to gather signatures on their property constituted a taking); Keystone Bituminous Coal Association $v$ DeBenedictis, 480 US 470, 506 (1987) (upholding law restricting coal mining).

$" 114$ S Ct 2309, 2319, 2321-22 (1994).

12 Id at 2320.

${ }^{13}$ Carol M. Rose, Property Rights, Regulatory Regimes and the New Takings Jurisprudence-An Evolutionary Approach, 57 Tenn L Rev 577, 580 (1990).

${ }^{14}$ Other commentators on Dolan have already predicted a substantial jurisprudential fallout from the decision. See Malcolm M. Murray, Life After Dolan: Will it Ever be the Same?, 24 Colo Law 59, 62 (1995) ("Dolan will fundamentally change the nature of judicial review of exactions decisions."); Robyn L. Sadler, Note, Dolan v. City of Tigard: Takings Doctrine Remains Vague Under the Rough Proportionality Standard, 31 Willamette L Rev 147, 173 (1995) ("The Court significantly heightened the standards and criteria for examining land use regulations."); Suzanna Glover-Ettrich, Casenote, A NewlyMinted Hurdle for City Planners: Dolan v. City of Tigard, 28 Creighton L Rev 559, 588 (1995) (noting that 'the 'rough proportionality' test departs from the traditional presumption of constitutionality given to legislatures enacting regulations under the police power"). 
that the new rough proportionality test imposes on regulatory exactions. Part I summarizes the Court's pre-Dolan decisions in the regulatory takings area, focusing particularly on the decline of property rights in the post-New Deal era and the signs of a property rights revival in recent decisions. Part II summarizes the Dolan decision and dissenting opinions. Particularly relevant is the poor relation dictum, which appears innocuously in the majority opinion but which potentially hints at a jurisprudential change of colossal proportions. Part III unpacks the rough proportionality test by examining the alternative tests that the Court considered and rejected, the cases the Court cited as inspiring its new test, and nontakings cases that have employed a similar test in analogous circumstances. The Comment concludes that whatever the Court intends for the future, it did not significantly raise the level of Takings Clause scrutiny in Dolan.

\section{A BRIEF HISTORY OF REGULATORY TAKINGS}

\section{A. Nuisance Theory and the Holmes Formulation}

The Supreme Court's regulatory takings analysis has traditionally followed two separate lines of reasoning. The first line draws on the common law of nuisance and is exemplified by the early case of Mugler $v$ Kansas. ${ }^{15}$ In Mugler, a beer brewer challenged a Kansas statute forbidding the brewing of alcoholic beverages as an uncompensated taking of property. The Court rejected this argument, holding that the police power of the state extends to the prohibition of nuisances. ${ }^{16}$ The brewing of beer was a legally cognizable nuisance because of its deleterious effect upon the public health, morals, and safety, and because Mugler had no right to create a nuisance, the prohibition of brewing was not a taking of property. The Mugler nuisance rationale, then, insulated an entire class of regulatory activity from Fifth Amendment scrutiny simply because it came within the expansive coverage of the state's police power. ${ }^{17}$ The Court has continued to apply the nuisance rationale in subsequent cases, ${ }^{18}$ although the

15 123 US 623 (1887).

16 Id at 671.

17 For a recent appraisal of the Mugler nuisance doctrine, see Nathaniel S. Lawrence, Regulatory Takings: Beyond the Balancing Test, 20 Urban Law 389, 394-95 (1988).

${ }^{18}$ See, for example, Keystone Bituminous Coal Association v DeBenedictis, 480 US 470, 506 (1987) (upholding state requirement that 50 percent of coal beneath certain structures be kept in place to prevent public nuisance of collapsing structures); Goldblatt $v$ Town of Hempstead, 369 US 590, 598 (1962) (upholding against takings challenge 
Supreme Court in one recent case collapsed the nuisance theory into the general requirement that the state's exercise of its police power serve a legitimate state interest. ${ }^{19}$

A second line of cases, derived from the landmark decision in Pennsylvania Coal Co. $v$ Mahon, ${ }^{20}$ employs a "diminution in value" rationale. In Mahon, the Court invalidated Pennsylvania's Kohler Act, which forbade the mining of anthracite coal in such a way as to cause the subsidence of any human habitation. Writing for the Court, Justice Holmes rejected the contention that the mining of coal was a public nuisance, and thus disposed of any effort to justify the statute under Mugler. ${ }^{21}$ This conclusion was not dispositive, however, as Holmes continued in what has become the most famous aphorism of takings law: "The general rule at least is, that while property may be regulated to a certain extent, if regulation goes too far it will be recognized as a taking." 22 Because the Kohler Act went "too far," it amounted to an uncompensated regulatory taking. ${ }^{23}$

Whether or not a regulation has gone too far under this analysis is determined in part by the extent to which the regulation diminishes the value of the property. ${ }^{24}$ However, Mahon itself provides no definitive standards as to how much regulators may diminish the value of a piece of property without paying

ordinance preventing continued operation of quarry in residential area); Miller $v$ Schoene, 276 US 272, 281 (1928) (upholding against takings challenge right of state to cut down privately owned trees that acted as hosts to fungus dangerous to apple trees growing in vicinity); Village of Euclid $v$ Ambler Realty Co., 272 US 365, 397 (1926) (upholding against takings challenge municipal ordinance zoning commercial buildings out of plaintiff's land); Hadacheck $v$ Sebastian, 239 US 394, 413-14 (1915) (upholding against takings challenge law barring operation of brick mill in residential area).

19 In Lucas v South Carolina Coastal Council, the Court noted that "prevention of harmful use' was merely our early formulation of the police power justification necessary to sustain (without compensation) any regulatory diminution in value ..." $112 \mathrm{~S} \mathrm{Ct}$ 2886, 2898-99 (1992). However, the Court did not abandon the nuisance theory altogether. According to the Lucas Court, land uses that would have been common law nuisances in the "background principles of the State's law of property and nuisance" continue to be subject to the nuisance abatement theory sanctioned in Mugler. Id at 2888. Thus, Lucas actually empowers the state to prohibit, without compensation, uses of land that would have been nuisances at common law. While Lucas may "diminish the number of cases that are subject to the nuisance exception," James W. Sanderson and Ann Mesmer, A Review of Regulatory Takings After Lucas, 70 Denver U L Rev 497, 508 (1993), it does not eliminate the Mugler nuisance theory. For an argument against the use of a nuisance rationale, see Joseph L. Sax, Takings and the Police Power, 74 Yale L J 36, 48-50 (1964).

260 US 393 (1922).

2I Id at 413 .

22 Id at 415 .

23 Id at 415-16.

24 Id at 413 . 
compensation. Thus, the case sets up a vague, ad hoc, and puzzling legal standard. ${ }^{25}$ The development of the "too far" test has consumed much of the Court's takings efforts in subsequent decisions. ${ }^{26}$

By formulating an ad hoc balancing approach to regulatory takings cases, ${ }^{27}$ Holmes prepared the Takings Clause to follow in the footsteps of economic substantive due process. In particular, Holmes's open-ended "too far" approach can be viewed as exposing the Takings Clause to the same proregulatory sentiment that ultimately contributed to the downfall of economic substantive due process. ${ }^{28}$ Indeed, Holmes himself expressed this sentiment seventeen years before Mahon, in his strong dissent in Lochner, the case known as the high point of the Court's economic substantive due process regime. ${ }^{29}$

${ }_{25}$ See Carol M. Rose, Mahon Reconstructed: Why the Takings Issue Is Still a Muddle, $57 \mathrm{~S}$ Cal L Rev 561, 566 (1984) (noting that courts incant the Holmes formulation "but actually decide cases on the basis of undisclosed, ad hoc judgments"). Rose notes that "[m]ore recent commentators have repeated the charge" that the Court's takings decisions since Mahon have led to an incoherent Takings Clause doctrine. Id at $562 \mathrm{n} \mathrm{6}$, citing Bruce Ackerman, Private Property and the Constitution 236 n 9 (Yale 1977), James L. Oakes, "Property Rights" in Constitutional Analysis Today, 56 Wash L Rev 583, 602-03 (1981), William B. Stoebuck, Police Power, Takings, and Due Process, 37 Wash \& Lee L Rev 1057, 1062-63 (1980), and Sandra E. Berchin, Comment, Regulation of Land Use: From Magna Carta to a Just Formulation, 23 UCLA L Rev 904, 912-13 (1976).

${ }_{26}$ See Raymond R. Coletta, Reciprocity of Advantage and Regulatory Takings: Toward a New Theory of Takings Jurisprudence, 40 Am U L Rev 297, 300 (1990) (noting that after Mahon, "courts spent most of their energies formulating a variety of tests to determine the Holmesian point of transition"); Ann T. Kadlecek, Note, The Effect of Lucas v. South Carolina Coastal Council on the Law of Regulatory Takings, 68 Wash L Rev 415, 418 (1993) ("Throughout the middle of the twentieth century, takings jurisprudence did not progress beyond, or clarify, the vague 'too far' test of [Mahon].").

${ }_{27}$ Mahon itself made it clear that a regulatory takings question "depends upon the particular facts." 260 US at 413. It has now "become a truism of the Court's takings jurisprudence that no 'set formula' exists to decide the issue." Lawrence, 20 Urban Law at 398 (cited in note 17). For cases repeating the truism of no set formula, see MacDonald, Sommer \& Frates $v$ Yolo County, 477 US 340, 348 (1986); Pennsylvania Central Transportation Co. $v$ New York City, 438 US 104, 124 (1978); Goldblatt, 369 US at 594.

${ }^{28}$ See text accompanying notes 33-36.

29198 US at 74-76. Lochner involved a New York statute setting maximum daily and weekly working hours for bakers. The Court invalidated the statute, finding that it infringed upon an individual's "general right to make a contract in relation to his business." Id at 53. The Court held that this freedom of contract was protected by the Due Process Clause of the Fourteenth Amendment. Id at 64.

Although Lochner involved the Due Process Clause of the Fourteenth Amendment and not the Takings Clause, Holmes's famous statement that "the Fourteenth Amendment does not enact Mr. Herbert Spencer's Social Statics," id at 75, is cited as a general indictment of any judicial effort to enshrine laissez-faire, antiregulatory sentiment in any substantive provision of the Constitution. See, for example, Industrial Union Department, AFL-CIO v American Petroleum Institute, 448 US 607, 723 (1980) (Marshall dissenting) (stating that "the Constitution 'does not enact Mr. Herbert Spencer's Social Statics") 
B. Carolene Products and the Post-Lochner Economic Rights Regime

The advent of the New Deal brought revolutionary changes to two significant areas of constitutional jurisprudence-economic liberties and the federal commerce power. The Court began to abandon its economic substantive due process doctrine around the same time that it shifted away from an antiregulatory stance on the Commerce Clause. ${ }^{30}$ In Nebbia $v$ New York, the Court sustained against a substantive due process challenge a statute creating a Milk Control Board to fix maximum and minimum retail prices for milk, stating that "a state is free to adopt whatever economic policy may reasonably be deemed to promote the public welfare ...." ${ }^{31}$ Similarly, in West Coast Hotel Co. $v$ Parrish, the Court held that a Washington statute setting minimum wages for women likewise did not violate substantive due process. ${ }^{32}$

The landmark decision arrived in Carolene Products. ${ }^{33}$ The Federal Filled Milk Act, which prohibited the shipment in interstate commerce of certain kinds of skimmed milk, was challenged as beyond Congress's Commerce Clause powers, and as a violation of both the Tenth Amendment and the Fifth Amendment Due Process Clause. In upholding the Act, the Court adopted a presumption of constitutionality in favor of legislation enacted under the police power of the state: such legislation would be upheld against a substantive due process challenge so long as it had a "rational basis." In footnote 4 , one of the most famous footnotes in the history of constitutional law, ${ }^{35}$ the Court made

(citation omitted) (emphasis added).

${ }^{30}$ The same year as it decided West Coast Hotel Co. $v$ Parrish, 300 US 379 (1937), the Supreme Court abandoned its narrow reading of the Commerce Clause and began approving federal New Deal legislation. See NLRB v Jones \& Laughlin Steel Corp, 301 US 1, 3031 (1937) (upholding power of National Labor Relations Board to issue orders concerning unfair labor practices under congressional commerce power); NLRB v Fainblatt, 306 US 601, 609 (1939) (sustaining reach of National Labor Relations Act to small garment manufacturer); United States v Darby, 312 US 100, 125 (1941) (sustaining congressional use of commerce power to regulate child labor).

31291 US 502, 537 (1934).

32300 US 379 (1937). West Coast Hotel overruled a prior economic substantive due process decision striking down a similar statute. See Adkins $v$ Children's Hospital, 261 US 525 (1923).

33304 US 144.

34 Id at 152.

35 Professor Owen Fiss called footnote 4 " $\mathrm{t}$ ] $]$ he great and modern charter for ordering the relations between judges and other agencies of government..." Owen Fiss, The Supreme Court, 1978 Term-Foreword: The Forms of Justice, 93 Harv L Rev 1, 6 (1979). For a summary of the scholarly superlatives used to describe footnote 4 , see Lewis $F$. 
it clear that the rational basis test applies only to the sort of economic challenges arising in the Lochner line of cases: "There may be a narrower scope of operation of the presumption of constitutionality when legislation appears on its face to be within a specific prohibition of the Constitution, such as those of the first ten Amendments, which are deemed equally specific when held to be embraced within the Fourteenth."36

Thus, Carolene Products created a two-tiered approach for judicial analysis of legislation adversely affecting personal freedoms. Legislative enactments affecting economic interests, such as the freedom of contract and vocation, would be subject to a highly deferential rational basis test. Statutes infringing upon specifically enumerated constitutional rights or prejudicing "discrete and insular minorities" would be subject to a higher standard of scrutiny. ${ }^{37}$ This bifurcation sounded the death knell for economic substantive due process ${ }^{38}$ and has had serious ramifications for the Takings Clause as well.

\section{Regulatory Takings Under Low Level Scrutiny}

Given that Carolene Products's stricter standard of review ostensibly extended to all specific constitutional prohibitions, one might have expected the Takings Clause to have received greater judicial protection than subsequent cases provided. However, it is now generally accepted that the Carolene Products line of cases not only rejected judicial use of the Fifth and Fourteenth Amendment Due Process Clauses to canonize laissez-faire economics, but also resolved to keep the judiciary from interfering with the growing regulatory state's control over economic activities and property interests. ${ }^{39}$ This shift was facilitated in the Takings

Powell, Jr., Carolene Products Revisited, 82 Colum L Rev 1087, 1087 n 4 (1982).

${ }_{35}$ Carolene Products, 304 US at $152 \mathrm{n} 4$.

37 Id at 153 \& $n 4$.

38 Cases subsequent to Carolene Products have made it clear that economic substantive due process is a judicial dead letter. See, for example, Ferguson $v$ Skrupa, 372 US 726, 732 (1963); Williamson v Lee Optical Co., 348 US 483, 491 (1955).

${ }_{39}$ The weight of recent scholarship has generally affirmed the proposition that property interests receive minimal scrutiny in the post-New Deal era. See Rose, 57 Tenn I Rev at $\mathbf{5 8 0}$ (cited in note 13) (arguing that Carolene Products complemented Village of Euclid v Ambler Realty Co., 272 US 365 (1926), by making property interests "poor relations in the world of rights"); Norman Karlin, Back to the Future: From Nollan to Lochner, $17 \mathrm{Sw}$ U L Rev 627, 629 (1988) (explaining that the Court only minimally scrutinizes cases in the property rights area in the wake of West Coast Hotel and Carolene Products); Herman Schwartz, Property Rights and the Constitution: Will the Ugly Duckling Become a Swan?, 37 Am U L Rev 9, 10 (1987) (After the death of substantive due 
Clause context by the open-ended "too far" approach adopted in Mahon. ${ }^{40}$

The advent of low level scrutiny for Takings Clause cases virtually crippled the regulatory takings theory. In Pennsylvania Central Transportation Co. $v$ New York City, the Court upheld New York's Landmarks Preservation Law, which empowered a city commission to designate buildings as historical landmarks. ${ }^{41}$ Once a building was so designated, its owner assumed a legal duty to keep its exterior in good repair and had to secure commission approval for any exterior alterations. ${ }^{42}$ Speaking through Justice Brennan, the Court upheld the regulation under a fact-specific, ad hoc balancing approach that focused on three manipulable factors: first, "[t]he economic impact of the regulation on the claimant"; second, "the extent to which the regulation

process, "[t]he Court [ ] rendered almost impotent even those constitutional clauses most directly concerned with protecting property, such as the 'takings' clause of the fifth amendment" and the Contracts Clause.) (citations omitted).

The scholarship on this point, however, has not been unanimous. Judge Learned Hand suggested that it would be too hasty to conclude that the Nebbia line of cases precludes "any judicial review of a statute [affecting only economic interests] because the choice made between the values and sacrifices in question did not commend itself to the court's notions of justice." Learned Hand, The Bill of Rights 45 (Harvard 1958). Professor Louis Lusky, who was Chief Justice Stone's law clerk at the time of the Carolene Products decision, calls a "misconception ... the notion that the Footnote calls for a denial of strict scrutiny in all cases involving property rights or economic interests." Louis Lusky, Footnote Redux: A Carolene Products Reminiscence, 82 Colum L Rev 1093, 1105 (1982).

40 Interestingly, in Dolan, Justice Stevens made the opposite point in criticizing the regulatory takings doctrine. $114 \mathrm{~S} \mathrm{Ct}$ at 2327 (Stevens dissenting). Stevens compared Holmes's approach in Mahon to the majority opinion in Lochner, stating "both doctrines are potentially open-ended sources of judicial power to invalidate state economic regulations that Members of this Court view as unwise or unfair." Id. While it is certainly true that the "too far" approach is highly discretionary and likely subject to the biases and opinions of members of the Court, the test does not necessarily predict the direction that such biases and opinions will cut. In this regard, one commentator has characterized the "too far" test "as nothing more than the due process test of reasonableness . . . ." Janice C. Griffith, Local Government Contracts: Escaping from the Governmental/Proprietary Maze, 75 lowa L Rev 277, 341 n 297 (1990).

While a Court ideologically opposed to economic regulation could easily dismiss land use regulations as "unreasonable," a Court sympathetic to regulation could just as easily accept regulations as reasonable without undertaking any searching legal inquiry. Indeed, the latter appears to have been the Court's predominant pattern under the "too far" approach until the last few years. See note 10 and accompanying text. If the Court had been using a bright line test-for example, that a nonnuisance land use restriction leading to a diminution in value entitled the owner to compensation-it would have been forced to find more regulatory takings than it did. Therefore, the combination of rational basis review, with its underlying presumption of constitutionality, and the Mahon "too far" approach, generally advances a proregulatory jurisprudence.

41438 US 104, 138 (1978).

${ }_{42}$ Id at 111-12. 
has interfered with distinct investment-backed expectations"; and third, "the character of the governmental action." ${ }^{43}$ Many commentators believe that Pennsylvania Central represents the nadir of Takings Clause scrutiny in the post-Carolene Products world. ${ }^{44}$

\section{The 1986 Term: Death and Resurrection of Regulatory Takings}

The Supreme Court's 1986 term brought three important Takings Clause decisions. ${ }^{45}$ Any one of them, decided on its own, surely would have led to speculation regarding the constitutional position of the Takings Clause. Taken together, the three cases created a deluge of commentary and criticism. ${ }^{46}$ The first decision, Keystone Bituminous Coal Association $v$ DeBenedictis, ${ }^{47}$ revisited the Mahon question through the lens of Pennsylvania Central, ${ }^{48}$ and therefore marked just one more step in the low level scrutiny line of cases. Confronted with a Pennsylvania Mine Subsidence Act virtually identical to the one invalidated in Mahon, ${ }^{49}$ the Court parted company with Justice Holmes. Although the Court attempted to distinguish Mahon on two counts, ${ }^{50}$ its validation of the Subsidence Act conflicted directly

43 Id at 124 (citations omitted).

4 See Richard A. Epstein, Yee v. City of Escondido: The Supreme Court Strikes Again, 26 Loyola LA L Rev 3, 15 (1992) (criticizing the Pennsylvania Central approach to regulatory takings as the "lowest imaginable standard of scrutiny"); Richard G. Wilkins, The Takings Clause: A Modern Plot for an Old Constitutional Tale, 64 Notre Dame L Rev 1, 28 (1989) (stating that Pennsylvania Central's reading of Mugler "virtually repeals the takings clause").

${ }_{45}$ Keystone Bituminous Coal Association v DeBenedictis, 480 US 470 (1987); Nollan v California Coastal Commission, 483 US 825 (1987); First English Evangelical Lutheran Church of Glendale $v$ County of Los Angeles, 482 US 304 (1987).

${ }^{46}$ Nollan, Keystone, and First English have generated over thirty-five law review articles, notes, and comments. See, for example, Charles $\mathrm{H}$. Clarke, The Owl and the Takings Clause, 25 St Mary's L J 693 (1994); Susan J. Krueger, Comment, Keystone Bituminous Coal Association v. DeBenedictis: Toward Redefining Takings Law, 64 NYU L Rev 877 (1989); Anne R. Pramaggiore, Comment, The Supreme Court's Trilogy of Regulatory Takings: Keystone, Glendale and Nollan, 38 DePaul L Rev 441 (1989).

47480 US 470 (1987).

48 See Pramaggiore, Comment, 38 DePaul L Rev at 472-75 (cited in note 46) (arguing that Keystone applied takings analysis employed in Pennsylvania Central, which resulted in substantial deference to legislature).

${ }_{49}$ The Subsidence Act required that 50 percent of the coal beneath certain structures be kept in place to provide surface support. Keystone, 480 US at 477 .

${ }_{50}$ First, unlike the Kohler Act, which merely balanced private economic interests, the Subsidence Act included specific findings by the Pennsylvania legislature that the Subsidence Act would serve the common welfare of the general public. Id at 485 . Second, unlike in Mahon, there was no record finding that "the Subsidence Act makes it impossi- 
with Mahon, leading many commentators to assert that the prior case had been overruled sub silentio. ${ }^{51}$ Additionally, the decision cast serious doubt on the viability of facial challenges to land use regulations. ${ }^{52}$ From the first takings decision of the 1986 term, then, one might have imagined that regulatory takings theories had gone the way of economic substantive due process and the dodo bird. One would have been wrong.

Although Keystone appeared to signal the end of Mahon, two cases decided later in the 1986 term revealed that the regulatory takings theory was still very much alive. In First English Evangelical Lutheran Church of Glendale $v$ County of Los Angeles, the Court held that when regulations "take" a landowner's property temporarily, the government must pay compensation for the value of the property for the duration of the taking. ${ }^{53}$ On the one hand, First English adds little to the Court's regulatory takings jurisprudence because it does not define "taking" and focuses solely on the question of remedies. ${ }^{54}$ On the other hand, the decision stands as a significant deterrent to municipal experimentation with land use schemes that could be declared takings. ${ }^{55}$ Thus, while First English does not in itself strengthen the regulatory takings theory, it does create a strong disincentive for government entities to regulate land use in constitutionally questionable ways.

The third relevant case in the 1986 term introduced a new twist to the regulatory takings doctrine, and brought the Takings Clause back onto center stage. In Nollan $v$ California Coastal

ble for [the landowners] to profitably engage in their business, or that there has been undue interference with their investment-backed expectations." Id.

${ }_{51}$ See, for example, Clarke, 25 St Mary's L J at 714 (cited in note 46) (concluding that Mahon did not survive Keystone's rejection of constitutional laissez-faire); Michael M. Berger, Happy Birthday, Constitution: The Supreme Court Establishes New Ground Rules for Land-Use Planning, 20 Urban Law 735, 739 (1988) ("The Keystone majority could not bring itself to overrule Pennsylvania Coal, so it tried to belittle it."); Robert H. Freilich, State and Local Government at the Crossroads: A Bitterly Divided Supreme Court Reevaluates Federalism in the Bicentennial Year of the Constitution, 19 Urban Law 791, 797 (1987) (arguing that Keystone distinguishes itself from Mahon on the basis of benefit to the public at large). But see Krueger, Comment, 64 NYU L Rev at 908 (cited in note 46) (concluding that Keystone does not overrule Mahon sub silentio).

52 See Susan Manges McMichael, Note, Mahon Revisited: Keystone Bituminous Coal Ass'n v. DeBenedictis, 480 U.S. 470 (1987), 29 Nat Resources J 1067, 1077 (1989); Derek Guemmer, Casenote, Constitutional Law: Keystone Bituminous Coal Association v. DeBenedictis: Pennsylvania Coal Revisited, 56 UMKC L Rev 153, 154 (1987).

53482 US 304, 322 (1987).

ss See Acton, 17 Stetson L Rev at 744 (cited in note 4).

65 For a discussion of the chilling effect of the First English decision on land use planning, see The Supreme Court, 1986 Term Leading Cases, 101 Harv L Rev 119, 246 (1987). 
Commission, the Nollans applied for a coastal development permit to demolish their existing beachfront bungalow and to replace it with a three-bedroom house. ${ }^{56}$ Finding that the construction of the new house would obstruct the public's view of the seashore, the California Coastal Commission conditioned approval of the building permit on the Nollans granting a lateral public easement over the beach portion of their property. ${ }^{57}$ The Supreme Court held that even though the Commission could have denied the building permit altogether, it could not condition the grant of the permit on a concession by the property owners that lacked an "essential nexus" to the justification for the prohibition. ${ }^{58}$ Because allowing members of the public already on the beach to walk along the Nollans' land would in no way address the barrier to visual access created by the new house, the Commission's attempted exaction was a taking without just compensation. ${ }^{59}$ As later explained in Dolan, "[t]he absence of a nexus left the Coastal Commission in the position of simply trying to obtain an easement through gimmickry, which converted a valid regulation of use into 'an out-and-out plan of extortion." "60

In dissent, Justice Brennan chided the majority for abandoning the rational basis test for the Takings Clause. ${ }^{61}$ Justice Scalia responded, in footnote 3 of the majority opinion, by arguing that even though Goldblatt $v$ Town of Hempstead ${ }^{62}$ assumed that the rational basis test applied to the Takings Clause, "that

${ }^{56} 483$ US 825,828 (1987).

57 Id.

58 Id at 837.

59 In Nollan, the Court applied the doctrine of unconstitutional conditions in the Takings Clause context. The doctrine was well explained later in Dolan: 'Under the wellsettled doctrine of 'unconstitutional conditions,' the government may not require a person to give up a constitutional right-here the right to receive just compensation when the property is taken for public use-in exchange for a discretionary benefit conferred by the government where the property sought has little or no relationship to the benefit." $114 \mathrm{~S}$ Ct at 2317, citing Perry $v$ Sindermann, 408 US 593 (1972), and Pickering $v$ Board of Education, 391 US 563, 586 (1968). For further commentary on the doctrine of unconstitutional conditions, see generally Cass R. Sunstein, Why the Unconstitutional Conditions Doctrine is an Anachronism (With Particular Reference to Religion, Speech, and Abortion), 70 BU L Rev 593 (1990); Kathleen M. Sullivan, Unconstitutional Conditions, 102 Harv L Rev 1415 (1989); Richard A. Epstein, The Supreme Court, 1987-Foreword: Unconstitutional Conditions, State Power, and the Limits of Consent, 102 Harv I Rev 4 (1988); Robert L. Hale, Unconstitutional Conditions and Constitutional Rights, 35 Colum L Rev 321 (1935).

to $114 \mathrm{~S}$ Ct at 2317, citing Nollan, 483 US at 837, quoting J.E.D. Associates, Inc. $v$ Town of Atkinson, 121 NH 581, 432 A2d 12, 14-15 (1981). J.E.D. has since been overruled by Town of Auburn $v$ McEvoy, $131 \mathrm{NH} 383,553$ A2d 317 (1988).

6. Nollan, 483 US at 843-45 (Brennan dissenting).

62369 US 590 (1962). 
assumption is inconsistent with the formulations of ... later cases." ${ }^{163}$ According to Scalia, the proper test for regulatory takings is whether the regulations "substantially advance' the legitimate state interest." ${ }^{2064}$

The majority's explicit rejection of the rational basis test provoked several law review comparisons between Nollan and Carolene Products. One commentator compared footnote 4 of Carolene Products to footnote 3 of Nollan.$^{65}$ Another scholar suggested that Nollan almost rehabilitates property rights after Carolene Products. ${ }^{66}$ Professor Norman Karlin speculated that Nollan and First English together may usher in a "new era in constitutional law decision making" to replace the Carolene Products regime. ${ }^{67}$ Other commentators debated the level of scrutiny imposed in Nollan, generally agreeing that it reflected either intermediate or strict scrutiny. ${ }^{68}$ Most commentators agreed that the decision would make land use regulation considerably more difficult. ${ }^{69}$

Despite the nearly unanimous agreement immediately after Nollan that the decision worked profound changes in regulatory

63 Nollan, 483 US at $835 \mathrm{n} 3$.

c4 Id, quoting Agins $v$ City of Tiburon, 447 US 255, 260-62 (1980).

65 Jerold S. Kayden, Land-Use Regulations, Rationality, and Judicial Review: The RSVP in the Nollan Invitation (Part I), 23 Urban Law 301, 309 (1991).

os Richard A. Epstein, Takings: Descent and Resurrection, 1987 S Ct Rev 1, 38 (1987).

67 Karlin, $17 \mathrm{Sw}$ U L Rev at 627 (cited in note 39). See also Robert A. Williams, Jr., Legal Discourse, Social Vision and the Supreme Court's Land Use Planning Law: The Genealogy of the Lochnerian Recurrence in First English Lutheran Church and Nollan, 59 U Colo L Rev 427, 473 (1988) (citing emergence of Nollan and First English as a "significant historical juncture" in Supreme Court discourse rivaled only by the New Deal and the Civil Rights movement).

${ }^{63}$ See Frank Michelman, Takings, 1987, 88 Colum L Rev 1600, 1607-08 (1988) (arguing that Nollan endorses semistrict judicial scrutiny); William A. Falik and Anna C. Shimko, The Takings Nexus: The Supreme Court Forges a New Direction in Land-Use Jurisprudence, 23 Real Prop, Prob \& Tr J 1, 37 (1988) (stating that Nollan's test is reminiscent of the strict scrutiny developed for the Equal Protection Clause); Pramaggiore, Comment, $38 \mathrm{DePaul} \mathrm{L} \mathrm{Rev} \mathrm{at} 481$ (cited in note 46) (reasoning that Nollan should be understood as an intermediate scrutiny case). But see Judith E. Caliman, Note, Private Rights v. Public Needs: Nollan v. California Coastal Commission, 1987 Detroit Coll L Rev 1201, 1215 (concluding that Nollan announces no new rule of law and has no significance beyond its facts).

69 See, for example, Mary M. Cizerle, Casenote, Nollan v. California Coastal Commission: Unprecedented Intrusion Upon a State's Judgment of the Proper Means to be Applied in Land Use Regulation, 21 John Marshall L Rev 641, 648 (1988) (characterizing Nollan as an unworkably rigid rule); Rigoberto V. Obregon and Rebekah L. Parker, Comment, 'Get it Right the First Time': A Message From the United States Supreme Court to Land Use and Environmental Regulators-A Comment on Nollan and First English, 7 UCLA J Envir L \& Policy 173, 177-78 (1988) (arguing that Nollan not only heightens scrutiny on regulators, but also shifts the burden of proof onto them). 
takings doctrine, most recent commentary generally asserts that the decision has had little effect on lower courts' analyses of land use regulations. ${ }^{70}$ If the Supreme Court intended to heighten scrutiny on the Takings Clause, the lower courts either misapprehended or disobeyed its directive. Moreover, Nollan left open the large question of what level of scrutiny the Supreme Court would apply to regulatory takings in future decisions. ${ }^{71}$ Enter Dolan.

${ }^{70}$ See Sandra Bailey, Comment, Land Use Regulations and the Takings Clause: Are Courts Applying a Tougher Standard to Regulators After Nollan?, 32 Nat Resources J 959, 965-66 (1992) (observing that despite dire predictions regarding Nollan, very few courts have actually applied a stricter standard of review); Elene Kapp, Comment, Government Land Use Regulations Affecting Private Property: Heightened Judicial Scrutiny After Nollan?, 18 W State U L Rev 357, 373 (1990) (pointing out that in the three years following Nollan there have been no heightened scrutiny progeny in the lower courts); Steven J. Lemon, Sandy R. Feinland, and Colin C. Deihl, Comment, The First Applications of the Nollan Nexus Test: Observations and Comments, 13 Harv Envir L Rev 585, 597 (1989) (concluding lower courts have not applied Nollan as a heightened scrutiny test); Phillip S. Simmons, Note, Commercial Builders Revisits Nollan: Constitutional Taking and the Limits of Regulatory Exactions, 13 Whittier L Rev 937, 937 (1992) (reasoning that Ninth Circuit opinion reflects view that Nollan scrutiny is less strict than many believed). But see Michael M. Berger, Late-Breaking News About Takings Law, C709 ALI-ABA 19, 27 (1992) (noting most cases since Nollan have applied strict scrutiny). See also John A. Saurenman, Keystone, Nollan and First English Three Years Later: How Fare the States?, 3 Emerging Issues St Const L 115, 150 (1990) (arguing that no clear pattern of dealing with the Nollan nexus test emerges from the state court decisions).

7 The one major takings decision between Nollan and Dolan, Lucas $v$ South Carolina Coastal Council, 112 S Ct 2886 (1992), involved a unique factual scenario, and therefore may be unimportant to the future of takings law. In Lucas, the Court held that a regulation depriving a property owner of all economically viable use of his land amounted to a per se taking within the meaning of the Fifth Amendment. Id at 2901-02. While dicta in the majority opinion may provide some clues as to the Court's intentions in the regulatory takings arena, the unreviewable lower court findings that the prohibition on improvements eliminated 100 percent of the value of Lucas's land are so unusual that Lucas may be a lightning bolt, unlikely to strike again and irrelevant to the future of takings law. See E. Paige Spencer, Note, Lucas v. South Carolina Coastal Council: A Narrow Exception to the Takings Clause, 3 Widener J Pub L 639, 706 (1993) (speculating that the 100 percent rule may never be tested because of the unique facts of Lucas).

On the other hand, Lucas should not be completely ignored "in view of the powerful recent momentum in reconfiguration of the Takings Clause." William C. Leigh and Bruce W. Burton, Predatory Governmental Zoning Practices and the Supreme Court's New Takings Clause Formulation: Timing, Value, and R.I.B.E., 1993 BYU L Rev 827, 847. For purposes of this Comment, though, it is sufficient to note that the Lucas holding was narrow, but that in light of its temporal proximity to Nollan, First English, and Dolan, it could arguably be viewed as one more way station on the road to heightened Takings Clause scrutiny. 


\section{THE DOLAN DECISION}

\section{A. The Facts}

Like Nollan, Dolan involved a municipality that conditioned the grant of a land improvement permit on the dedication of a portion of the property to public use. ${ }^{72}$ Pursuant to a state land use planning statute, ${ }^{73}$ the city of Tigard, Oregon identified traffic congestion in its central business district as a problem and adopted a plan for a pedestrian/bicycle pathway to encourage the use of alternatives to automobile transportation. In addition to traffic congestion, Tigard had also experienced flooding in its Fanno Creek. The city therefore adopted a drainage plan, which called for the preservation of a greenway along the floodplain and the construction of various improvements to minimize flooding problems. ${ }^{74}$

Florence Dolan owns a plumbing and electric supply store on a 1.67-acre parcel in the central business district of Tigard. Hoping to redevelop the site, she applied for a permit nearly to double the size of the store and to pave a thirty-nine-space parking lot. In considering her application, the City Planning Commission found it "reasonable to assume that customers and employees of the future uses of this site could utilize a pedestrian/bicycle pathway adjacent to this development for their transportation and recreational needs." ${ }^{75}$ In the Commission's opinion, this pathway "could offset some of the traffic demand on [nearby] streets and lessen the increase in traffic congestion."76 The Commission also found that the addition of the paved parking lot, an impervious surface, would increase stormwater flow into the already strained Fanno Creek. ${ }^{77}$ Based on these findings, the Commission approved Dolan's building permit on the conditions that she dedicate the portion of her property lying within the creek's floodplain to be used as a public greenway and that she dedicate an additional fifteen-foot strip of land adjacent to the floodplain to the city for use as a pedestrian/bicycle pathway. ${ }^{78}$

72 Dolan, 114 S Ct at 2312.

73 Or Rev Stat $\$ \S 197.005-197.860$ (1991).

74 Dolan, 114 S Ct at 2313.

${ }^{75}$ Id at 2314-15, quoting City of Tigard Planning Commission Final Order No. 91-09 PC, App to Pet for Cert G24.

${ }_{76}$ Dolan, 114 S Ct at 2315.

$77 \mathrm{Id}$.

${ }^{78}$ Id. 
Dolan challenged these exactions as uncompensated regulatory takings, but lost before the Land Use Board of Appeals, the Oregon Court of Appeals, and the Oregon Supreme Court. ${ }^{79}$ The Oregon Supreme Court interpreted Nollan as holding that an "exaction is reasonably related to an impact if the exaction serves the same purpose that a denial of the permit would serve." Shortly thereafter, the United States Supreme Court granted certiorari. $^{81}$

\section{B. The Majority Opinion}

Chief Justice Rehnquist delivered the opinion of the Court, in which Justices O'Connor, Scalia, Kennedy, and Thomas joined. ${ }^{82}$ Rehnquist addressed the question left open by Nollan: "What is the required degree of connection between exactions imposed by the city and the projected impacts of the proposed development." ${ }^{\text {B3 }}$ After summarizing the facts of the case and the holdings of some frequently cited takings decisions, Rehnquist described the relationship between Nollan and Dolan. The first question to be addressed in exactions cases is "whether the 'essential nexus' exists between the 'legitimate state interest' and the permit condition exacted by the city. ${ }^{384}$ In Nollan, Rehnquist explained, the Court found no such nexus, and therefore did not have to proceed to the second question, which he framed as "the required degree of connection between the exactions and the projected impact of the proposed development."

In Dolan, the Court had no difficulty finding an essential nexus between the city's exactions and the reduction of traffic congestion and flooding. ${ }^{86}$ However, the Court had never enunciated a precise standard to govern the second prong of the exactions test: the required impact/exaction relationship. For guidance, the majority looked to state precedent addressing that precise question.

The majority broke the state cases down into three groups. First, New York and Montana had adopted "very generalized

79 Id at 2315-16.

Bo Dolan v City of Tigard, 317 Or 110, 854 P2d 437, 443 (1993), rev'd, 114 S Ct 2309 (1994).

${ }^{81}$ Dolan v City of Tigard, 114 S Ct 544, 544 (1993).

${ }^{82}$ Dolan, 114 S Ct 2309.

${ }^{83}$ Id at 2312.

84 Id at 2317 , quoting Nollan, 483 US at 837.

85 Dolan, $114 \mathrm{~S}$ Ct at 2317.

${ }^{86}$ Id at 2317-18. 
statements as to the necessary connection between the required dedication and the proposed development...." ${ }^{187}$ The majority held that this standard was "too lax to adequately protect" property interests. ${ }^{88}$ A second group of states had followed the lead of the Illinois Supreme Court and adopted a "specifi[c] and uniquely attributable" test. ${ }^{89}$ Under this approach, "if the local government cannot demonstrate that its exaction is directly proportional to the specifically created need," the exaction becomes a taking. ${ }^{90}$ The Court rejected this standard also, stating that "given the nature of the interests involved," the Constitution does not require "such exacting scrutiny."

Having rejected both permissive and strict approaches, the Court homed in on an "intermediate position, requiring the municipality to show a 'reasonable relationship' between the required dedication and the impact of the proposed development." A number of state courts and one federal circuit had already adopted this position. ${ }^{93}$ The Court expressed its view that "the 'reasonable relationship' test adopted by a majority of the state courts is closer to the federal constitutional norm than either of those previously discussed." ${ }^{\text {How }}$ Hower, the Court declined to "adopt it as such, partly because the term 'reasonable relationship' seems confusingly similar to the term 'rational basis' which describes the minimal level of scrutiny under the Equal Protection Clause of the Fourteenth Amendment."95 Instead, the Court described the requirement of the Fifth Amendment as one of "rough proportionality." The Court explained this test: "No precise mathematical calculation is required, but the city must make some sort of individualized determination that

87 Id at 2318-19, citing Billings Properties, Inc. $v$ Yellowstoñe County, 144 Mont 25, 394 P2d 182 (1964), and Jenad, Inc. $v$ Village of Scarsdale, 18 NY2d 78, 271 NYS2d 955 (1966).

s4 Dolan, 114 S Ct at 2319.

$*$ Id.

so Id.

91 Id.

s2 Id.

s3 Id, citing Simpson $v$ City of North Platte, 206 Neb 240, 292 NW2d 297, 301 (1980), Jordan $v$ Village of Menomonee Falls, 28 Wis $2 \mathrm{~d} 608,137$ NW2d 442 (1965), Collis $v$ City of Bloomington, 310 Minn 5, 246 NW2d 19, 23-24 (1976), City of College Station v Turtle Rock Corp, 680 SW2d 802, 807 (Tex 1984), Call $v$ City of West Jordan, 606 P2d 217, 220 (Utah 1979), and Parks $v$ Watson, 716 F2d 646, 651-53 (9th Cir 1983).

s4 Dolan, 114 S Ct at 2319.

95 Id. The Court might have added: “ . . . and confusingly similar to Justice Brennan's dissenting position in Nollan." 
the required dedication is related both in nature and extent to the impact of the proposed development., ${ }^{966}$

Applying this test to the facts before it, the Court concluded that neither the exaction of the bicycle/pedestrian pathway nor the exaction of the greenway was roughly proportional to the projected impact of Dolan's proposed development. ${ }^{97}$ As to the greenway, the city's insistence upon public ownership constituted the Fifth Amendment defect. The Court would have found no constitutional infirmity with a requirement that Dolan leave the floodplain undeveloped. However, "[t]he city [had] never said why a public greenway, as opposed to a private one, was required in the interest of flood control. ${ }^{m 88}$ Tigard had demanded one of the most essential sticks in the bundle of property rights-the right to exclude others-even though the paved parking lot would not create a need for a publicly owned greenway.

As to the pathway, the fatal error appeared to lie in the indeterminate nature of the Commission's findings. "The city simply found that the creation of the pathway 'could offset some of the traffic demand ... and lessen the increase in traffic congestion.'"'99 The Court quoted Oregon Supreme Court Justice Peterson's dissenting opinion below: “The findings of fact that the bicycle pathway system 'could offset some of the traffic demand' is a far cry from a finding that the bicycle pathway system will, or is likely to, offset some of the traffic demand."100 According to the majority, under the rough proportionality test, the city bore the burden "to quantify its findings in support of the dedication, ${ }^{101}$ a burden of proof that it failed to meet.

\section{The Dissenters}

Two dissenting opinions were filed in Dolan. Justice Stevens, joined by Justices Blackmun and Ginsburg, began by criticizing the majority for purporting to rely on state cases that invalidated ordinances on the basis of state law "or unspecified grounds roughly equivalent to Nollan's 'essential nexus' requirement.."102 The opinion further chided the majority for overriding a rational

96 Id at 2319-20.

97 Id at 2321-22.

ss Id at 2320 .

s9 Id at 2321-22.

${ }^{100}$ Id at 2322, quoting Dolan v City of Tigard, 317 Or 110, 854 P2d 437, 447 (1993)

(Peterson dissenting).

${ }^{101}$ Dolan, 114 S Ct at 2322.

102 Id at 2323 (Stevens dissenting). 
and impartial land planning scheme by narrowly focusing on a single stick from the bundle of property rights. Most significantly, Stevens criticized the majority for departing from the traditional presumption of constitutionality by resurrecting "a species of substantive due process analysis that it firmly rejected decades ago." ${ }^{103}$ In conclusion, the opinion emphasized that the burden of proving that a regulatory taking occurred belongs with the landowner. ${ }^{104}$

Justice Souter sounded a less severe tone in his dissent. Souter's opinion began by stating that the majority announced a test that it did not apply. ${ }^{105}$ Souter would have resolved the entire issue under Nollan, and stated that he would have found the required rational connection between the exactions and the governmental interest. ${ }^{106}$ Souter disagreed with the majority most on whether the burden of proof should rest with the landowner or the municipality. Souter would have left the burden on the landowner under "the usual rule in cases involving the police power that the government is presumed to have acted constitutionally." $" 107$

\section{The "Poor Relation" Dictum}

Whatever the effect of the rough proportionality test on regulatory exactions, Dolan's dictum ultimately may exercise more influence than its holding. Just after it announced the rough proportionality test, and before it applied that test, the majority took a brief aside to rebut a criticism raised in Justice Stevens's dissenting opinion. Stevens maintained that the city's exactions were "a species of business regulation that heretofore warranted a strong presumption of constitutional validity." 108 The majority responded that "simply denominating a governmental measure as a 'business regulation' does not immunize it from constitutional challenge on the grounds that it violates a provision of the Bill of Rights." ${ }^{109}$ In this regard, the majority noted that precedents under the First and Fourth Amendments indicated that commercial or business entities could also claim constitutional protec-

$100^{\circ}$ Id at 2331.

107 Id, citing Goldblatt $v$ Town of Hempstead, 369 US 590, 594-96 (1962), and United States v Sperry Corp, 493 US 52, 60 (1989).

${ }^{10 \mathrm{~S}}$ Dolan, $114 \mathrm{~S}$ Ct at 2325 (Stevens dissenting).

10 Dolan, 114 S Ct at 2320. 
tion. ${ }^{110}$ Then, in the middle of this otherwise innocuous paragraph, Rehnquist dropped a potential bombshell: "We see no reason why the Takings Clause of the Fifth Amendment, as much a part of the Bill of Rights as the First Amendment or Fourth Amendment, should be relegated to the status of a poor relation in these comparable circumstances."111 Having made this pronouncement, the majority opinion proceeded to apply the rough proportionality test to the facts of Dolan.112

The poor relation comment, as dictum, is subject to different interpretations. One could dismiss it as a mere response to an antagonistic position raised by the dissent. However, if footnote 3 of Nollan, which rejected the rational basis test for Takings Clause cases, ${ }^{113}$ raised a hue and cry among Court watchers, the poor relation dictum should do still more. Even prior to Dolan, Professor Carol Rose had observed that Carolene Products made property interests "poor relations in the world of rights," foreshadowing the very words employed in Dolan. ${ }^{114}$ If the Court meant to do no more with its poor relation comment than rebut Stevens's commercial regulation argument, it unwittingly opened Pandora's box.

To commentators awaiting hints of the Court's regulatory takings direction after Nollan and Lucas, the poor relation dictum certainly will sound like a repudiation of Carolene Products. Taken at face value, the comment suggests that the entire post-New Deal bifurcation of economic regulations and personal liberties rests on shaky ground. If the Court were to begin treating property rights with the same respect it accords speech and privacy interests, Carolene Products and its progeny would be relegated to the dustbin of judicial history. ${ }^{115}$

${ }_{110}$ The majority relied principally upon Marshall $v$ Barlow's, Inc., 436 US 307, 324 (1978) (invalidating statute authorizing warrantless searches of business premises on Fourth Amendment grounds), and Central Hudson Gas \& Elec. Corp v Public Serv. Comm'n, 447 US 557, 571-72 (1980) (holding Commission's order prohibiting advertising by a utility company to promote use of electricity violates First Amendment).

11 Dolan, $114 \mathrm{~S}$ Ct at 2320.

112 See id at $2320-22$.

113 See note 65-69 and accompanying text.

114 Rose, 57 Tenn L Rev at 580 (cited in note 13). Within the same set of familial metaphors, property interests in the post-New Deal era have been characterized as a "red-headed stepchild," David H. Safavian, Comment, Re-Taking the Fifth Amendment-Property Rights Revisited, 1993 Detroit Coll L Rev 955, 955 (1993), and as an "ugly duckling," Schwartz, 37 Am U L Rev at 9 (cited in note 39).

115 Professor Epstein has advocated that the Court carry over its First Amendment analysis to the Takings Clause. Richard A. Epstein, Property, Speech, and the Politics of Distrust, 59 U Chi L Rev 41, 42-43 (1992). Such a paradigm shitit would rest upon the 
The death of Carolene Products would be an event of tremendous significance. ${ }^{116}$ Spillover effects from a vigorous implementation of the poor relation dictum would flow well beyond the Takings Clause. Already, commentators have suggested that Nollan may have set the Court up to use the Equal Protection Clause more actively in land regulation situations. ${ }^{117}$ Similarly, there have been calls for a return to economic substantive due process $^{118}$ and a heightening of Privileges and Immunities Clause scrutiny ${ }^{119}$ in relation to land use regulation. If the post-Carolene Products dual system of strict and minimal scrutiny were to be abolished, other economically oriented provisions of the Constitution, such as the Contracts Clause and the Due Process Clauses, might be reinvigorated significantly. In short, a

belief that "the dominant mode of thinking about property rights during the past fifty years has been a mistake of constitutional dimensions." Id at 41. By implication, if the Court were to treat the Takings Clause in pari materia with the First Amendment, it would have to rewrite the bulk of its post-New Deal takings jurisprudence. In a similar vein, Fourth Amendment jurisprudence illustrates the shift from "the early twentiethcentury Court's veneration of property as the central constitutional value," to "the midtwentieth-century Court's relative indifference to property interests ..." William C. Heffernan, Property, Privacy, and the Fourth Amendment, 60 Brooklyn L Rev 633, 688 (1994). After Katz v United States, 389 US 347 (1967), "and the numerous cases that flowed from it," the Fourth Amendment seemed to protect "property interests only to the extent that it protect[ed] privacy interests." Heffernan, 60 Brooklyn L Rev at 634. "[T]he contemporary Court's cautious rehabilitation of property as a constitutionally protected interest" within the Fourth Amendment, id at 688, coincides with its "interest in elevating property rights above the lowly status into which they had fallen following the crisis of legitimacy the Court suffered in the late 1930s," id at 651 (citing Dolan poor relation dictum). Thus, the Carolene Products regime undermined even the property interests protected by the Fourth Amendment, a constitutional provision subjected to increasingly heightened scrutiny in the following constitutional generation. Taken as a reaffirmation of all constitutional property interests, the poor relation dictum suggests that this regime should be reconsidered.

116 According to Professor Brilmayer, Carolene Products is no longer a case, but instead "a line of reasoning, and one so venerable as to have achieved almost axiomatic status in a world where virtually every other proposition of Constitutional law is best considered controversial." Lea Brilmayer, Carolene, Conflicts, and the Fate of the "InsideOutsider", 134 U Pa L Rev 1291, 1291 (1986).

117 William A. Falik and Anna C. Shimko, The "Takings" Nexus-The Supreme Court Chooses a New Direction in Land-Use Planning: A View from California, 39 Hastings L J 359,391 (1988).

118 Randall T. Shepard, Land Use Regulation in the Rehnquist Court: The Fifth Amendment and Judicial Intervention, 38 Cath U L Rev 847, 847 (1989). See also Ross A. Macfarlane, Comment, Testing the Constitutional Validity of Land Use Regulations: Substantive Due Process as a Superior Alternative to Takings Analysis, 57 Wash L Rev $715,733,743$ (1982) (arguing that substantive due process offers greater flexibility than the Takings Clause, and is therefore a superior tool for assessing the constitutionality of land use regulations).

119 Keith R. Denny, Note, That Old Due Process Magic: Growth Control and the Federal Constitution, 88 Mich L Rev 1245, 1247 (1990). 
broad reading of the poor relation dictum would suggest that the Court is poised to jettison a paradigm that has governed a large part of its constitutional jurisprudence for the better part of sixty years. $^{120}$

\section{UNPACKING THE Rough PROPORTIONALITY TEST}

The poor relation dictum may or may not signal an end to the Carolene Products regime, but the answer to that question does not lie within the four corners of the Dolan opinion. Just as it would have been impossible to predict the tremendous influence of footnote 4 of Carolene Products from a dissection of that opinion, ${ }^{121}$ so it is impossible to tell just how far the Court will take its Dolan dictum. Dolan was a five-to-four decision, and whether it represents a harbinger of a new single-level scrutiny for all substantive protections of the Constitution will depend on the personalities and dynamics at work on the Supreme Court. Given the gargantuan implications of the poor relation dictum, far-reaching speculation regarding the future of the Carolene Products regime is tempting. However, many lower court decisions failed to bear out similar dramatic pronouncements in the aftermath of Nollan. ${ }^{122}$ Therefore, the recent history of Takings Clause jurisprudence demands restraint in forecasting Dolan's domain.

While sweeping predictions are speculative at best, the Court did not leave the legal community wholly without means to begin assessing the impact of the Dolan dictum. In formulating the new rough proportionality test, the Court gave commentators a mechanism by which to interpret its dictum. Presumably, if the

${ }^{120}$ The death of Carolene Products might also have implications for the Court's treatment of the Commerce Clause. It was no accident of history that West Coast Hotel, 300 US 379 (upholding statute setting minimum wages for women against due process challenge), was decided in the same year as $N L R B v$ Jones \& Laughlin Steel Corp, 301 US 1 (1937) (watershed case expanding Commerce Clause to accommodate New Deal programs). Insofar as a proregulatory jurisprudence included both aggrandizement of enumerated federal powers and a cutback on individual freedom of contract and private property rights, it is reasonable to expect that a reversion to a pro-property rights jurisprudence could signal correlative limitations on the congressional commerce power. This prediction is supported by the Court's recent decision in United States $v$ Lopez, $115 \mathrm{~S}$ Ct 1624 (1995) (striking down Gun-Free School Zone Act of 1990 as exceeding Congress's Commerce Clause authority).

${ }^{121}$ See Powell, 82 Colum $L$ Rev at 1090 (cited in note 35) (Justice Stone was using the cryptic language of footnote 4 to "spark debate over ideas that he had not developed fully" and not to outline "a comprehensive theory of constitutional adjudication."), citing Alpheus Mason, Harlan Fiske Stone: Pillar of the Law 513 (Viking 1956).

122 See note 70 and accompanying text. 
majority wanted the poor relation dictum to signal its dissatisfaction with the jurisprudential status quo, its test would apply a higher standard of scrutiny. Conversely, if the rough proportionality test does not depart significantly from past practice, the poor relation dictum may seem less promising to property rights activists and less ominous to regulators. In any event, analysis of the rough proportionality test, as applied by the Dolan Court, can help make sense of the poor relation dictum.

Three areas of inquiry suggest that the rough proportionality test does not significantly elevate the level of scrutiny on regulatory exactions. First, the state court standards that the Court considered and rejected offer clues as to what the rough proportionality test is not. Second, the six cases employing a reasonable relationship test, which the Court cited as being "closer to the federal constitutional norm,"123 offer clues as to the kind of scrutiny to be imposed by the rough proportionality test. Finally, it is possible to locate similar tests in nontakings cases, and to analyze the level of scrutiny that they impose on claimed violations of other provisions of the Constitution.

\section{A. The Standards Rejected}

As previously noted, the Dolan Court examined three sets of state court standards in arriving at the rough proportionality test. This Section briefly addresses the two roads not taken: the "specifically and uniquely attributable" test and the unnamed "generalized statements." The Court's rejection of the latter approach is altogether unsurprising, given that it conflicted openly with Nollan. Jenad, Inc. $v$ Village of Scarsdale ${ }^{125}$ and Billings Properties, Inc. $v$ Yellowstone County, ${ }^{126}$ the two state court decisions cited for this approach, imposed no greater scrutiny on exactions than the infinitely malleable reasonableness standard that always applies to evaluations of the police power. ${ }^{127} \mathrm{Nei}-$ ther case made any effort to link the development impact and the exaction, whether qualitatively, as required by Nollan, or even quantitatively, as ultimately required by Dolan. In this regard, the reasonableness standard differs little from the rational basis test explicitly rejected in Nollan. ${ }^{128}$ Thus, the Dolan Court's dis-

124 Id at 2318-19.

125 18 NY2d 78, 271 NYS2d 955 (1966).

125144 Mont 25, 394 P2d 182 (1964).

127 Jenad, 271 NYS2d at 958-59; Billings Properties, 394 P2d at 186.

${ }^{124}$ See Simmons, Note, 13 Whittier L Rev at 940 n 17 (cited in note 70) (arguing the 
approval of the approach embodied in Jenad's and Billings Properties's "generalized statements" offers scant information on the constitutional position of the Takings Clause.

If the Court's rejection of Jenad and Billings Properties says little, its rejection of the "specifically and uniquely attributable" test says much. Pioneer Trust and Savings Bank $v$ Village of Mount Prospect, ${ }^{129}$ the source of this test, represents the paradigmatic enunciation of a strict scrutiny standard in the exactions context. ${ }^{130}$ The test requires a very tight fit between the exaction and the development impact: "[I]f the burden cast upon the subdivider is specifically and uniquely attributable to his activity, then the requirement is permissible; if not, it is forbidden and amounts to a confiscation of private property ...."131 Those courts that have adopted this standard have used it "primarily to shield developers from demands for schools and parklands, and related in lieu fees." 132

In rejecting the Pioneer Trust test, the Dolan Court passed up a golden opportunity to substantiate its poor relation dictum. The "specifically and uniquely attributable" standard has the flavor of the strict scrutiny tests that surround the preferred freedoms of the Bill of Rights. ${ }^{133}$ If the Court intended to break

rational basis test is a reasonableness standard). See also Nollan, 483 US at $844 \mathrm{n} 1$ (Brennan dissenting) (Although the phraseology may differ from case to case, the inquiry in each case is the same.).

129 Il 2d 375, 176 NE2d 799 (1961).

${ }^{130}$ Pioneer Trust's "specifically and uniquely attributable" test has been generally recognized as imposing a strict standard on regulatory exactions. See, for example, Thomas W. Ledman, Note, Local Government Environmental Mitigation Fees: Development Exactions, the Next Generation, 45 U Fla L Rev 835, 844 (1993) (stating test imposes "a very strict judicial standard"); Jane E. Schukoske, Housing Linkage: Regulating Development Impact on Housing Costs, 76 Iowa L Rev 1011, 1049 (1991) (characterizing test as a "strict standard"); S. Mark White, Development Fees and Exemptions for Affordable Housing: Tailoring Regulations to Achieve Multiple Public Objectives, $6 \mathrm{~J}$ Land Use \& Envir L 25, 26 n 7 (1990) (referring to test as a "strict causation-benefit standard"); John J. Delaney, Larry A. Gordon, and Kathryn J. Hess, The Needs-Nexus Analysis: A Unified Test for Validating Subdivision Exactions, User Impact Fees and Linkage, 50 L \& Contemp Probs 139, 149 (1987) (stating test is "very stringent").

131 Pioneer Trust, 176 NE2d at 802.

132 Judith Welch Wegner, Moving Toward the Bargaining Table: Contract Zoning, Development Agreements, and the Theoretical Foundations of Government Land Use Deals, 65 NC L Rev 957, 1017-18 (1987). Of the four cases other than Pioneer Trust that Dolon cited as employing the "specifically and uniquely attributable" test, three invalidated the exactions in question, J.E.D. Associates, Inc. $v$ Town of Atkinson, 121 NH 581, 432 A2d 12, 15 (1981); McKain v Toledo City Plan Commission, 26 Ohio App 2d 171, 270 NE2d 370, 374-75 (1971); Frank Ansuini, Inc. $v$ City of Cranston, 107 RI 63, 264 A2d 910, 91314 (1970), and one was remanded for further factual determinations, Divan Builders, Inc. $v$ Planning Board, 66 NJ 582, 334 A2d 30, 41 (1975).

${ }^{133}$ More precisely, the "specifically and uniquely attributable" test resembles the 
with Carolene Products and elevate the Takings Clause to full equality with its constitutional cousins, it would logically have chosen the "specifically and uniquely attributable" test over the rough proportionality test. Instead, its choice of a permutation of the reasonable relationship standard suggests that property interests remain subject to far-reaching regulation through exactions.

\section{B. Cases Inspiring the Rough Proportionality Test: The} "Reasonable Relationship" Test

Strictly speaking, the Court did not officially adopt the reasonable relationship test that was "closer to the federal constitutional norm than either of those previously discussed." 134 Indeed, it rejected the reasonable relationship terminology partly because of its semantic similarity to the rational basis test. ${ }^{135}$ Still, although the level of scrutiny imposed by a reasonable relationship test is not necessarily equivalent to the level of scrutiny imposed by a rough proportionality test, the Court did not otherwise distinguish the two tests. Rather, the Court seemed generally satisfied with the consensus position of the state courts, noting "general agreement" with only "semantical differences...."136 Therefore, while the reasonable relationship test may not be the precise standard mandated by Dolan, for now it affords a good approximation of the required level of scrutiny on regulatory exactions in the wake of that decision. ${ }^{137}$

Following the lead of the Wisconsin Supreme Court's seminal decision in Jordan $v$ Village of Menomonee Falls ${ }^{138}$ at least sev-

\footnotetext{
"narrow tailoring" requirement employed in First Amendment cases. As explained in Frisby $v$ Schultz, "[a] statute is narrowly tailored if it targets and eliminates no more than the exact source of the 'evil' it seeks to remedy." 487 US 474, 485 (1988) (citation omitted). This is much the same as saying that an exaction is permissible so long as it remedies the exact impact of the new development.

134 Dolan, 114 S Ct at 2319.

I3s Id.

136 Id.

${ }^{137}$ One commentator has suggested that "in announcing the rough proportionality" test, the Court did not merely change the name of the 'reasonable relationship' test ... [ [but] created a standard different than the 'reasonable relationship' test adopted by the state courts." Glover-Ettrich, Casenote, 28 Creighton L Rev at 584 (cited in note 14). While it may be that in identifying the rough proportionality test with the reasonable relationship test the Court is pulling a proverbial "bait-and-switch," such duplicity is hardly apparent from the face of the Dolan opinion. Dolan does not define the rough proportionality test in any great detail. Therefore, the state cases that allegedly inspired the new test provide the only concrete guidance as to its content.
}

${ }^{139} 28$ Wis $2 \mathrm{~d} 608,137$ NW2d 442 (1965). 
en other jurisdictions have adopted some form of the reasonable relationship test. ${ }^{139}$ Dolan cited five of these decisions, including Jordan, and one decision of the Ninth Circuit as evidence of the majority position on the required impact/exaction relationship. ${ }^{140}$ Dolan provides the following description of this reasonable relationship test:

The distinction, therefore, which must be made between an appropriate exercise of the police power and an improper exercise of eminent domain is whether the requirement has some reasonable relationship or nexus to the use to which the property is being made or is merely being used as an excuse for taking property simply because at that particular moment the landowner is asking the city for some license or permit. ${ }^{141}$

In two of the cases cited by Dolan, the courts found the required reasonable relationship lacking. Both cases, however, suggest that a well informed municipality could meet the requirement without significantly altering the manner or extent of its exactions program. In Parks $v$ Watson, the municipality admitted that the value of the easement it sought in exchange for development approval greatly exceeded the impact of the development, but asserted that there was no taking because the municipality could have withheld approval altogether. ${ }^{142}$ However, this "lesser power inheres in the greater power" reasoning had been soundly defeated in a long line of unconstitutional conditions cases. ${ }^{143}$ Indeed, few fact patterns could have been easier for a court applying the unconstitutional conditions doctrine than one including the unapologetic admission that the municipality was using its police power leverage to acquire a benefit disproportionate to the impact of the development. The municipality had preordained its own defeat by admitting that it sought to gain a windfall through its regulatory authority, and, after Parks, no

${ }^{139}$ Nicholas V. Morosoff, Note, “Take' My Beach, Please!”: Nollan v. California Coastal Commission and a Rational-Nexus Constitutional Analysis of Development Exactions, 69 BU L Rev 823, 868-70 \& n 301 (1989).

${ }^{140}$ Dolan, 114 S Ct at 2319.

${ }^{141}$ Id, quoting Simpson $v$ City of North Platte, 206 Neb 240, 292 NW2d 297, 301 (1980).

${ }_{142} 716$ F2d 646, 650-52 (9th Cir 1983).

143 The Parks court cited Perry v Sindermann, 408 US 593 (1972), Frost \& Frost Trucking Co. v Railroad Commission, 271 US 583 (1926), Stephenson v Binford, 287 US 251 (1932), Speiser $v$ Randall, 357 US 513 (1958), and Elfbrandt $v$ Russell, 384 US 11 (1966). Parks, 716 F2d at 650, 652. 
municipality with competent legal advice should make the same mistake. Thus, the failure of the municipality to meet the reasonable relationship test in Parks does not suggest that the standard imposes any significant hurdle to the exactions program of a well informed municipality.

The judicial invalidation of the municipality's exaction in Simpson $v$ City of North Platte was equally unindicative of elevated scrutiny under the reasonable relationship test. ${ }^{144}$ The case involved the conditioning of a permit to build a fast food restaurant upon the dedication of land for the construction of a public street extension. Two constitutional defects invalidated the exaction. First, the city did not even allege that it planned to build the street extension once the land was dedicated. Although the city's comprehensive plan proposed an extension of the existing street, "no project was immediately contemplated whereby the street would be constructed nor [was] there any evidence regarding what the particular project would involve."145 Thus, the city was merely engaging in "land banking": reserving the land for some possible but unspecified and unscheduled future use. ${ }^{146}$ Second, the city provided no record evidence that the construction of the restaurant would create the need for a street extension. If it did not, then the exaction would have transgressed Nollan's essential nexus requirement; the issue of proportionality would have been irrelevant. ${ }^{147}$ Therefore, the Dolan Court's citation to Simpson's reasonable relationship merely reaffirms its commitment to the essential nexus requirement, and says little about the proportionality requirement.

Parks and Simpson indicate that the reasonable relationship test does have teeth at the margin. When a city expressly admits that it seeks to gain a regulatory windfall, or engages in overt land banking, courts should invalidate the condition almost as a matter of course. However, evidence that the test has teeth in extreme cases does not suggest that it imposes exacting scrutiny in most situations. The contrary may in fact be true. If the paradigmatic cases for invalidation under the reasonable relationship test are instances of extreme abuse of the exaction pow-

144206 Neb 240, 292 NW2d 297 (1980).

145292 NW2d at 301.

${ }^{145} \mathrm{Id}$.

147 Justice Stevens's dissenting opinion in Dolan asserts that Simpson employed "unspecified grounds roughly equivalent to Nollan's 'essential nexus' requirement." $114 \mathrm{~S}$ $\mathrm{Ct}$ at 2323 (Stevens dissenting). 
er, courts applying the test to more ordinary exactions will likely be deferential to municipal authorities.

The cases cited in Dolan upholding exactions support this intuition. The four cases, Jordan, ${ }^{148}$ Call $v$ City of West Jordan, ${ }^{149}$ City of College Station $v$ Turtle Rock Corp, ${ }^{150}$ and Collis $v$ City of Bloomington, ${ }^{151}$ present the typical exactions pattern, in which municipalities require land developers to dedicate a portion of their land for some public use in exchange for development approval. ${ }^{152}$ In these cases, subdividers challenged municipal ordinances requiring dedication of percentages of the subdivided land for use as parks, schools, flood-control zones, and recreational facilities, and the courts uniformly found reasonable relationships between the impacts of the developments and the exacted land. ${ }^{153}$

Two related facets of the cases illustrate the liberality of this reasonable relationship standard. First, these cases treat reasonableness of the relationship between the impact and the exaction as a particular and fact-specific inquiry. In Turtle Rock, the case that addresses this issue most directly, the court began its discussion of the takings issue with an obligatory but sloganistic observation: "The question of whether a police power regulation is proper or whether it constitutes a compensable taking is a question of law and not of fact."154 Nevertheless, noted the court, a consideration of all the circumstances is required. Ultimately, the reasonableness test is a "fact-sensitive" inquiry, requiring "careful analysis of the facts...."155 The procedural posture of the case illustrated well the importance of this observation. The trial court had granted summary judgment in favor of the developer, and the court of appeals had affirmed. ${ }^{156} \mathrm{De}$ spite its invocation of the question-of-law standard, the Texas Supreme Court reversed and remanded for trial based on its

148137 NW2d 442.

149606 P2d 217 (Utah 1979).

150680 SW2d 802 (Tex 1984).

151310 Minn 5, 246 NW2d 19 (1976).

152 See Connors and High, $50 \mathrm{~L} \&$ Contemp Probs at 70 (cited in note 4 ) ("The most common and least controversial type of exaction is an intradevelopment dedication of land for streets, sidewalks, water and sewer lines, and, more recently, land for recreational or educational purposes.").

${ }^{153}$ Jordan, 137 NW2d at 448-49; Call, 606 P2d at 220; Turtle Rock, 680 SW2d at 806; Collis, 246 NW2d at 26.

${ }^{154} 680 \mathrm{SW} 2 \mathrm{~d}$ at 804 (citations omitted).

155 Id.

${ }^{156}$ City of College Station $v$ Turtle Rock Corp, 666 SW2d 318 (Tex Ct App 1984). 
analysis of the facts. Thus, whether or not the reasonable relationship test is nominally a question of law, it was applied in Turtle Rock as a question of fact.

The other three cases also support the proposition that the reasonable relationship test is basically a fact-driven standard. In Collis, the Minnesota Supreme Court characterized the "reasonable portion" requirement as "a facts-and-circumstances test" that "consider[s] the myriad [ ] factors which may bear on a municipality's needs for certain kinds of facilities and the relationship of a particular subdivision to those needs." ${ }^{157}$ Similarly, the Jordan court engaged in what amounted to a sufficiency-ofthe-evidence review, inquiring whether there was "a reasonable basis for the finding that the need for the acquisition was occasioned by the activity of the subdivider."158 Finally, the Call court gave the takings issue and the reasonable relationship test such short shrift that it is impossible to discern exactly where the court stood on the question of fact/question of law issue. However, the brevity of the Call court's discussion suggests that the trial court's treatment of the factual determinations was dispositive. ${ }^{159}$

What emerges from the cases is a consensus position that, although a reviewing court may have some role in assessing the reasonableness of the impact/exaction relationship, that determination is a fact-specific inquiry best left to the lower court, or perhaps even to the administrative body that made the original determination of proportionality. ${ }^{160}$ This suggests that the reasonable relationship test is nothing close to strict scrutiny. As a general proposition, appellate courts reviewing governmental actions under strict scrutiny do not rest their conclusions upon fact-specific inquiries undertaken by lower courts. ${ }^{161}$ Leaving

157246 NW2d at 26.

iss 137 NW2d at 447 .

${ }^{169}$ The district court denied the developer's request for injunctive relief. Call, 606 P2d at 221-22.

${ }^{160}$ How much deference the judicial trier of fact should accord the planning commission's quasi-legislative determinations regarding the proportionality of the impact/exaction relationship is a difficult issue of administrative law not squarely addressed in Dolan. See George C. Christie, Judicial Review of Findings of Fact, $87 \mathrm{Nw}$ U L Rev 14 (1992). For present purposes it is sufficient to note that regardless of how little deference a trier of fact might accord quasi-legislative determinations, deference to the lower court's finding on appellate review is generally indicative of a low standard of scrutiny.

161 See, for example, Robert C. Power, Affirmative Action and Judicial Incoherence, 55 Ohio St L J 79, 159 (1994) (arguing fact-intensive analysis in equal protection cases is at odds with strict scrutiny); Lori Jayne Hoffman, Note, Fatal in Fact: An Analysis of the Application of the Compelling Governmental Interest Leg of Strict Scrutiny in City of 
the adjudication of a constitutional right to the discretion of the trier of fact tends to weaken the right. ${ }^{162}$ While there has been some suggestion that appellate deference to a fact-intensive inquiry by a lower court is characteristic of intermediate scrutiny, ${ }^{163}$ it is flatly inconsistent with the protective scrutiny usually accorded the preferred freedoms in the Carolene Products regime. ${ }^{164}$ Thus, when the Turtle Rock court characterized the reasonable relationship test as "fact-sensitive," it was signalling its resolve not to become enmeshed in deciding the proportionality question on appellate review. Not surprisingly, the reasonable relationship test is usually used to affirm the constitutionality of exactions. ${ }^{165}$

The second reason to believe that the reasonable relationship test does not impose heightened scrutiny lies in the courts' failure to analyze the impact/exaction relationship according to any numerical or quantitative metric. Dolan made clear that "[n]o precise mathematical calculation is required ...."166 Yet, the treatment of the rough proportionality test as a fact-intensive inquiry assumes some sort of quantification of the impact/exaction relationship; implicit in the rough proportionality and reasonable relationship tests is the requirement that the development impact be approximately equal to the exaction. As discussed below, Jordan, Collis, Turtle Rock, and Call demonstrate that the metric for comparing the development impact to the exaction is not primarily economic, and that even when numbers are considered by courts, they are at best very round numbers. Again, this imprecision is not indicative of heightened scrutiny.

Richmond v. J.A. Croson, 70 BU L Rev 889, 908 (1990) (stating that in Croson, Justice Stevens "rejected the imposition of strict scrutiny and advocated a more fact-specific standard").

${ }_{162}$ See Richard H. Fallon, Jr., Making Sense of Overbreadth, 100 Yale L J 853, $858 \mathrm{n}$ 28 (1991) (arguing fact-specific analysis under the First Amendment results in too little protection of speech because it overemphasizes the harm of the regulated speech and minimizes the systemic benefits of free speech).

${ }_{163}$ See Power, 55 Ohio St L J at 158-59 n 284 (cited in note 161) (treating intermediate scrutiny as consistent with fact-intensive analysis); Schwartz, $37 \mathrm{Am}$ U L Rev at 36-37 (cited in note 39) (noting intermediate scrutiny under the Takings Clause is fact-specific).

164 Indeed, the reasonable relationship test's fact-specific, ad hoc approach to exactions is reminiscent of the Pennsylvania Central approach, which has been characterized as eviscerating the Takings Clause. See note 44 and accompanying text.

165 Other state court decisions employing a reasonable relationship test to validate exactions include Holmes $v$ Planning Board, 78 AD2d 1, 433 NYS2d 587 (1980), and Home Builders Association v City of Kansas City, 555 SW2d 832 (Mo 1977).

$166114 \mathrm{~S}$ Ct at 2319. 
The Jordan court made a greater effort than did the other courts to cite record evidence regarding the quantitative relationship between the proposed development's projected impact and the land exacted. The court noted testimony by a planning expert that "for a good environment for human habitation for each family in the area there should be a minimum of three thousand square feet of land devoted to park and school purposes."167 The ordinance in question required the developer to dedicate two hundred dollars worth of land per residential lot for use as school grounds, parks, or recreational areas. The link between the needs created by the development of each residential lot and the dedication of two hundred dollars worth of land per lot was explained as follows: "After some study of average land values in the village, the village planning commission and the village board determined that land valued at $\$ 200$ would by and large provide the added park and school lands required for each family ....".168

Two significant observations should be made about this approach. First, the metric used to evaluate the need created, and consequently the required dedication, was not directly related to the actual economic impact of the development. A system of more exacting scrutiny would determine the proportionality issue by ascertaining the marginal economic burden imposed by each additional residential lot on the surrounding community. Instead, the expert testimony in Jordan addressed how much recreational and educational land use was necessary to create "a good environment for human habitation." ${ }^{\text {"169 }}$ The implicit in-kind compensation question, and hence the relevant metric, was ascertained according to an evaluation of subjective human needs at a highly generalized level, and not according to a more empirically quantifiable evaluation of the economic burdens imposed by the particular development. ${ }^{170}$

Second, the comparative valuation issue was addressed in very round numbers. The court indicated that three thousand square feet were required per developed lot, and that this "by

167 Jordan, 137 NW2d at 448.

169 Id at 446.

IE9 Id at 448.

130 The Jordan court's approach to comparative valuation is a difficult one to handle with empirical precision. See Richard A. Epstein, Takings: Private Property and the Power of Eminent Domain 200 (Harvard 1985) ("Measuring the value of the property taken and the compensation provided in exchange is especially difficult because the benefits of many programs are in the form of public goods, which are notoriously difficult to value."). 
and large" accounted for the required dedication of two hundred dollars worth of land. ${ }^{171}$ The only link between these two figures was an unspecified "study of average land values." parently, the court considered the specific quantitative findings of the study not important enough to warrant mention. While it is difficult to generalize about this approach with so few details, it is clear that this permutation of the reasonable relationship test is a far cry from the sort of fastidious quantification required by stricter scrutiny, such as the "specifically and uniquely attributable" test.

If Jordan's approach to quantification is significant because it eschews economic comparisons and mathematical precision, the other three cases are significant in that they eschew any mention of quantitative findings. ${ }^{173}$ The Collis court simply noted that "[i]t may be impossible to determine to everyone's satisfaction the precise point at which" the required relationship exists. ${ }^{174}$ The court simply accepted a legislative determination by the city that as a general rule 10 percent of the developed land should be dedicated because developers could "rebut this statement in a judicial review proceeding ...." 175 Thus, the court permitted the city to shift the burden of proof regarding quantification to the developer by making a generalized legislative determination. The Turtle Rock and Call courts ignored the quantification problem altogether. Given that neither court undertook empirical or numerical inquiries, the reasonable relationship test appears in both these cases to have been understood as only requiring qualitative symmetry, and perhaps prohibiting grossly disproportionate exactions. ${ }^{176}$

That the reasonable-relationship courts avoided economic and quantitative analysis suggests that future courts will likewise defer to the factual determinations of municipal regulators in exactions litigation. If a court accepts as prima facie evidence of proportionality a city's estimate of the land necessary for healthy human habitation, then the burden of adducing hard

171 Jordan, 137 NW2d at 446.

172 Id.

173 This is not necessarily to say that the lower courts made no quantitative findings or individualized determinations, which Dolan's rough proportionality test does ultimately require. Rather, it suggests that if such determinations were made, they were not considered relevant or reviewable on appeal.

${ }^{174} 246$ NW2d at 25, quoting John D. Johnston, Jr., Constitutionality of Subdivision Control Exactions: The Quest for a Rationale, 52 Cornell L Q 871, 924 (1967).

175 Collis, 246 NW2d at 27.

176 See Turtle Rock, 680 SW2d at 806-07; Call, 606 P2d at 221. 
empirical evidence to the contrary, a potentially Herculean task, shifts to the developer. ${ }^{177}$ Calculating the economic value of public goods is generally a difficult undertaking, ${ }^{178}$ and this burden will be particularly heavy on the developer, who is in a far worse position than the municipality to quantify the need for public goods created by the improvement. ${ }^{179}$ Therefore, while the reasonable relationship test does require some finding of quantitative proportionality, it allows the municipality considerable latitude in defining that proportionality. "Rough proportionality" is rough indeed.

Fact-specific yet number-shy, the reasonable relationship test invites affirmance of development exactions in all but the most extortionate circumstances. Deferring to lower courts and administrative bodies, courts of appeal usually employ the test in a loose, qualitative fashion. Dolan's adoption of an exaction test drawn from the principle of reasonable relationship tends to negate, rather than to support, the proposition that the Takings Clause warrants increased judicial scrutiny after Dolan.

\section{Related Tests in Nontakings Contexts}

Although the rough proportionality test is new to the Takings Clause, an equivalent concept has been employed by federal courts of appeal in a variety of constitutional contexts. On the one hand, it is somewhat difficult to isolate uses of this rough proportionality concept because of the semantic similarity of the terms "rational basis" and "reasonable relationship," a source of confusion recognized by the Dolan majority. ${ }^{180}$ However, it is

${ }^{177}$ In Dolan itself, it appeared that a flat assertion of proportionality by the city would have sufficed to shift the burden of proof back to the developer. The fatal flaw as to the pathway exaction was the city's finding that the pathway "could" offset some traffic demand, rather than it "will" or "is likely to" offset some traffic demand. Dolan, $114 \mathrm{~S} \mathrm{Ct}$ at 2322. The Court characterized this finding as a failure by the city "to quantify its findings ... beyond the conclusory statement that it could offset some of the traffic demand generated." Id. Therefore, the Court implied that the substitution of "will" for "could" would have legitimized the exaction.

${ }_{17 \%}$ See Epstein, Takings at 200 (cited in note 170).

${ }^{173}$ See, for example, Elizabeth Becker and Cotton M. Lindsay, Does the Government Free Ride?, 37 J L \& Econ 277, 277 (1994) (Ascertaining valuations of public goods from private individuals may be problematic because free rider considerations make individuals reluctant to reveal their valuations to the government.); Christine M. Augustyniak, Economic Valuation of Services Provided by Natural Resources: Putting a Price on the "Priceless”, 45 Baylor L Rev 389, 392-96 (1993) (noting that lack of distinct markets in public goods, such as recreational sites, poses special challenges to valuing public goods through private demand).

$1 \times 14 \mathrm{~S} \mathrm{Ct}$ at 2319 . The mess is further compounded by the Court's interchangeable 
possible to identify some nontakings cases that have employed rough proportionality concepts the same as or similar to that announced in Dolan.

Thus, even though the Court in Dolan cited no precedents in announcing the test, it was clearly not beginning with a blank slate. The slogan "rough proportionality" has been used in a number of other cases, many of them fairly irrelevant to the current discussion. ${ }^{181}$ Other cases, however, have used a rough proportionality or similar standard to express the same sort of requirement that the Court expressed in Dolan. An exhaustive study of all such cases is not feasible, but a survey of a few cases approving governmental exactions or penalties on a basis similar to the Dolan standard reinforces the proposition that the Dolan test does not impose heightened scrutiny on takings claims.

The key concept defining the rough proportionality test is that when the government requires a party to surrender a vested right in exchange for receiving a government benefit, or causing a social detriment, the value of the right surrendered and the right bestowed must be comparable. A First Circuit case illustrates the use of this concept under the First Amendment. In Vote Choice, Inc. $v$ DiStefano, the court rejected a First Amendment challenge to a state law requiring that recipients of public gubernatorial campaign funds observe statutory limits on campaign spending. ${ }^{182}$ Although First Amendment doctrine is quite different from Takings Clause doctrine, the court's analysis was remarkably similar to the analysis of Nollan and Dolan. ${ }^{183}$ The court

use of the terms "rational relation" and "rational basis." See, for example, City of Mesquite $v$ Aladdin's Castle, Inc., 455 US 283, 302-03 (1982); Zablocki v Redhail, 434 US 374, 407 (1978) (Rehnquist dissenting); Ohio Bureau of Employment Services v Hodory, 431 US 471,489 (1977). This sort of linguistic wrangling appears to have been the motive for the creation of the rough proportionality test, which avoids the words "rational," "reasonable," "basis," and "relationship."

${ }_{181}$ See, for example, Hotel Employers Association v Gorsuch, 669 F2d 1305, 1309 (9th Cir 1982) (employing rough proportionality concept under Federal Water Pollution Control Act); Atlantic Richfield Co. $v$ American Airlines, Inc., 836 F Supp 763, 774-77 (N D Okla 1993) (analyzing and rejecting the "proportionate rule" under CERCLA).

One week after Dolan, the Court handed down its decision in Johnson v De Grandy, holding that the Voting Rights Act is not violated where "in spite of continuing discrimination and racial bloc voting, minority voters form effective voting majorities in a number of districts roughly proportional to the minority voters' respective shares in the voting-age population." 114 S Ct 2647, 2651 (1994) (emphasis added). See also United States v Gigante, 39 F3d 42, 47 (2d Cir 1994) (holding that sentencing guidelines require some rough proportionality between the weight of the evidence of uncharged conduct and degree of adjustment or departure).

1624 F3d 26, 43 (1st Cir 1993).

${ }^{183}$ The DiStefano analysis was based largely on one of the Supreme Court's holdings 
noted that "the law achieves a rough proportionality between the advantages available to complying candidates . . . and the restrictions that such candidates must accept to receive these advantages." ${ }^{184}$ Given the absence of coercion and the voluntariness of the transaction, "the state exact[ed] a fair price from complying candidates in exchange for receipt of the challenged benefits. ${ }^{185}$

While it might be thought that the use of the rough proportionality standard under the First Amendment, a provision of the Bill of Rights usually subject to strict scrutiny, indicates an elevation of scrutiny in Dolan, the very opposite is apparent from the face of DiStefano. At the same time the DiStefano court was upholding the spending cap for public fund recipients, it was striking down a Political Action Committee ("PAC") disclosure requirement under the First Amendment strict scrutiny standard. ${ }^{186}$ This indicates that the rough proportionality test is reserved for exaction-type situations and that it is significantly easier to meet than traditional strict scrutiny. The disclosure requirement, where no reciprocity of advantage was in question, was required to "serve a compelling governmental interest" and demonstrate a "substantial nexus . . . between the served interest and the information to be revealed." 187 On the other hand, the court deemed the exacted conditions constitutionally permissible even though they did not achieve "exact balance," because they did not "stray beyond the pale, creating disparities so profound that they bec[ame] impermissibly coercive."188 DiStefano illustrates the substantial difference between the strict scrutiny characteristic of the "preferred" freedoms of the Bill of Rights ${ }^{189}$ and the rough proportionality test employed to determine "fair price" in exchanges between the government and the people.

in Buckley $v$ Valeo, 424 US 1, 143 (1976) (upholding expenditure limitations for candidates accepting federal funds under Subtitle $\mathrm{H}$ of the Federal Election Campaign Act of 1971). DiStefano, 4 F3d at 31-33.

is DiStefano, 4 F3d at 39.

is Id.

1s: Id at 29. PACs were required to file a notice listing their goals and purposes, the positions they planned to advocate, the names of candidates they intended to support, and the names and addresses of their officers. The Court invalidated this requirement because it failed to meet the following two-part test: "(1) the statute as a whole must serve a compelling governmental interest, and (2) a substantial nexus must exist between the served interest and the information to be revealed." Id at 31-32 (citations omitted).

${ }^{167}$ Id at 32, citing Brown $v$ Socialist Workers '74 Campaign Commission, 459 US 87, 91-92 (1982), and Buckley, 424 US at 64.

i*3 DiStefano, 4 F3d at 38.

$1 *$ In Murdock v Pennsylvania, 319 US 105, 115 (1943), the Court explained that the First Amendment enjoys a preferred position in the catalogue of constitutional rights. 
A related line of reasoning is discernible in Equal Protection Clause challenges to development impact fees. In Shell Island Investment $v$ Town of Wrightsville Beach, the Fourth Circuit upheld a sewage infrastructure impact fee assessed against a developer of a residential area that would have increased the municipality's population by over 20 percent and accounted for 75 percent of all new growth. ${ }^{190}$ Shell Island is particularly useful in that it distinguishes, perhaps unwittingly, the sort of rational basis review rejected by the Dolan Court and the sort of rational relationship analysis it accepted. ${ }^{191}$ Under traditional rational basis review, the court inquires whether the legislative classification is rationally related to a permissible governmental objective under any conceivable set of facts. ${ }^{192}$ In Shell Island, the developer made no claim that impact fees were a per se irrational means of meeting infrastructure costs, but rather that the amount of fees assessed against the developer bore no rational relationship to the actual amount of needed improvement to the infrastructure. ${ }^{193}$ In assessing this claim, the court quietly slipped from its general discussion of "reasonable basis" review to a more specific discussion of whether "the impact fee bore a rational relationship between the burden and its bearer." ed differently, the court inquired whether the need created by the development was "in any way disproportionate" to the costs assessed on the developer. ${ }^{195}$ In the language of DiStefano, one might have inquired whether the city was charging Shell Island a "fair price" for its use of the municipal infrastructure.

The court's response was almost identical to the Dolan formulation. "[M]athematical precision [was] not required" to sustain the reasonableness of the relationship. ${ }^{196}$ The district court had found that Shell Island's anticipated growth would create a necessity for additional sewage capacity, and this determination

1901990 WL 41050, *5-7 (4th Cir) (unpublished opinion).

191 Shell Island is another good example of confusing low level scrutiny terminology. The opinion employs the term "reasonable basis" in lieu of "rational basis," and the term "rational relationship" to capture the "reasonable relation" or "rough proportionality" concept employed in Dolan. 1990 WL 41050, *5-6.

${ }_{192}$ See, for example, Morey v Doud, 354 US 457, 464 (1957).

1931990 WL $41050, * 5$.

194 Id *6. It is unclear from the opinion whether the court recognized that it was departing from a rational basis analysis in discussing the "rational relationship" requirement. The discussion is permeated with traditional rational basis slogans. The analysis, however, is more in line with the reasonable relationship approach that gave birth to the rough proportionality test.

195 Id.

196 Id. 
was sufficient. Even though the city had described its fee adjustment as "arbitrary," this, the Court determined "was simply a concession that the threefold increase figure was not a mathematically precise one ...."197 The city had made some attempt to quantify the need created by the development, and, "arbitrary" or not, it was sufficient.

This reasoning is instructive in interpreting the Dolan mandate that the municipality "make some sort of individualized determination," though not necessarily a "precise mathematical calculation." ${ }^{198}$ Although it seems rather unlikely, given recent trends in the Court's jurisprudence, that the Court would accept a concededly arbitrary assessment of the impact/dedication relationship, Shell Island's use of the "rational relationship" concept hints at the level of fact finding required under a rough proportionality test. Once the city recites its finding as to the impact/dedication relationship, the reasonable relationship test requires minimal review of that determination.

DiStefano and Shell Island illustrate the use of the rough proportionality concept in situations where the private party is seeking some government benefit or subsidy, such as campaign funds or the use of public infrastructure. The same inquiry sometimes arises where the private party's conduct creates a social detriment. There, the issue is the proportionality of the relationship between the impact of the conduct and the penalty imposed. Two federal circuit court opinions illustrate the use of the rough proportionality concept under the Eighth Amendment and the Double Jeopardy Clause of the Fifth Amendment.

In United States $v$ Tilley, the Fifth Circuit was faced with a criminal defendant's claim that prosecution for a drug offense-already the subject of a successful civil forfeiture action-constituted double jeopardy in violation of the Fifth Amendment. ${ }^{199}$ The Fifth Circuit noted that under the Supreme Court's precedent, civil forfeiture sanctions constitute criminal punishment only where the "amount of the sanction is 'overwhelmingly disproportionate' to the damages caused by the wrongful conduct and thus bears no rational relation to the goal of compensating the government for its loss . . ." ${ }^{\prime 200}$ Characterizing this "rational relation" test as a requirement of "rough pro-

${ }^{200}$ Id at 298, quoting United States $v$ Halper, 490 US 435, 448-49 (1989). 
portionality between the [ ] sanction and the resulting governmental and societal costs," ${ }^{201}$ the Tilley court rejected the claim that the $\$ 650,000$ forfeiture constituted punishment. Although the costs to the government and society of the defendant's drug dealing were "incapable of exact measurement," ed various estimates of these costs and proceeded at a macroeconomic level. ${ }^{203}$ On the basis of estimated national figures, the court concluded that the required rough proportionality between the impact of the defendant's illegal actions and the amount of the forfeiture was present. ${ }^{204}$ Thus, Tilley's approach to rough proportionality suggests that the test may be employed by courts as a fairness mantra to approve, without undertaking detailed factual inquiries, property exactions that do not seem grossly inequitable.

Courts have used a similar rough proportionality test in Eighth Amendment cruel and unusual punishment cases. In United States v Lizza Industries, Inc., the Second Circuit held that "[c]alculation of [RICO] forfeiture[s] based on gross rather than net profits from illegal activity does not destroy [the] rough proportionality" between the magnitude of the defendant's criminal enterprise and the punishment dispensed. ${ }^{205}$ This notion of the punishment quantitatively fitting the crime may be compared to the DiStefano court's "fair price" slogan for First Amendment exactions. As in every other rough proportionality test, this test. did not require "complex computations" of the impact/penalty relationship. ${ }^{206} \mathrm{~A}$ quick eyeballing of the situation by the court appeared to suffice. Substantial deference was accorded to the trier of fact, in this case the district judge, suggesting that appellate review of rough proportionality determinations is narrow in scope.

201 Tilley, 18 F3d at 299.

202 Id.

${ }^{203}$ In order to justify the amount of drug proceeds confiscated in the particular case, the court cited estimates that illegal drug sales cost the government and society $\$ 60-120$ billion per year. Id, citing Martin Wolf, Thinking about drug legalisation, Fin Times Section I at 19 (Sept 4, 1989), 134 Cong Rec S15630 (Oct 12, 1988) (statement of Sen Danforth), and Drug Abuse Cost to U.S. May Be 125 Billion Dollars-Study, Reuter Library Report, LEXIS (Sept 5, 1991).

204 Interestingly, the Tilley court cited two recent takings cases in its opinion. 18 F3d at 300, citing Lucas v South Carolina Coastal Council, 112 S Ct 2886, 2894 (1992), and Pennsylvania Central, 438 US at 124.

205775 F2d 492, 498 (2d Cir 1985).

${ }^{206}$ Id. 
This survey of cases arising under the free speech, equal protection, cruel and unusual punishment, and double jeopardy provisions of the Constitution cannot provide a definitive interpretation of the Dolan rough proportionality test. Rather, it illustrates the sorts of reasoning that courts use, and the sorts of results that courts reach, when employing analogous tests. The mere fact that all four cases surveyed affirmed the governmental actions in question does not necessarily prove that the test imposes low level scrutiny. However, the manner in which the courts assessed proportionality does suggest deference to the executive entity whose decision instigated the litigation and to the trier of fact below. If this pattern carries over to the land use area in the wake of Dolan, municipal regulators will not find their individualized determinations carefully scrutinized by the judiciary, and the poor relation dictum will remain just that-dictum.

\section{CONCLUSION}

However strong the temptation to pronounce Carolene Products dead and to call Dolan its eulogy, such a pronouncement would be premature. The only accurate expositor of a cryptic Supreme Court dictum is the Supreme Court in future cases. Nollan received a hero's welcome from property rights activists and libertarians, and rotten eggs from environmentalists and land use regulators. Eight years later, however, it has spawned no elevated scrutiny in the lower courts, belying the expectations of detractors and advocates alike. Now along comes Dolan-apparently elevating the Takings Clause, in dictum, from its inferior status in the pantheon of the Bill of Rights, and at the same time seemingly repudiating the entire Carolene Products constitutional regime. However, close examination suggests that whatever use the Court makes of the poor relation dictum in the future, Dolan does not significantly elevate Takings Clause scrutiny. The revolution may come tomorrow, but it did not come today.

The basis for this conclusion is the fairly low level of scrutiny that the new rough proportionality test imposes on exactions. It is difficult to fit the test within the traditional trifurcated scheme of low, intermediate, and strict scrutiny; many commentators made similar, unsuccessful attempts with Nollan's rational nexus test. $^{207}$ Still, analysis of the rough proportionality test indicates 
that it will not impose significant new hurdles to land use regulations or to exactions. In rejecting the "specifically and uniquely attributable" test, in characterizing the new requirement as something akin to the reasonable relationship test, and in choosing a form of words that signals a jurisprudential approach almost invariably approving of governmental action, the Dolan Court failed to substantiate the poor relation dictum. Instead, it formulated a test that will fit snugly into the jurisprudential status quo.

While it would be hasty to trumpet the death of Carolene Products on the basis of Dolan, it would be overly skeptical to ignore the Court's renewed interest in the Takings Clause. Recent cases such as Nollan, First English, Lucas $v$ South Carolina Coastal Council, and Dolan itself do indicate a partial revival of constitutional property rights. Given the truly strict scrutiny with which Court watchers read every word of every opinion concerning such "hot" areas of constitutional law as takings, it would be naive to assume that the poor relation dictum was promulgated with no polemical intent. Indeed, the poor relation dictum may flourish into a constitutional revolution to replace Carolene Products's famed footnote 4. However, if the Dolan majority intended to make property rights full relatives in the Bill of Rights family, it forgot to invite the Takings Clause to the family reunion.

ber that in footnote 3 of Nollan, Justice Scalia disclaimed any relationship between the rational basis test and the standard of review employed under the Takings Clause. According to Scalia, governmental regulations of property must "substantially advance [ ] the legitimate state interests." 483 US at 834 (citation omitted). Although some commentators characterized this test as intermediate scrutiny, see, for example, Dennis J. Coyle, Takings Jurisprudence and the Political Cultures of American Politics, 42 Cath U L Rev 817,856 (1993), the traditional intermediate scrutiny test requires that classifications serve "important governmental objectives" and that they be "substantially related to the achievement of those objectives." Craig $v$ Boren, 429 US 190, 197 (1976). It therefore seems less important to force the takings test into verbal slogans tailored to other provisions of the Constitution than to inquire whether the takings standards enunciated by the Court will actually make it more difficult for regulators to prevail in exaction litigation. This Comment suggests that however one might characterize the rough proportionality test, it does not bring the Takings Clause near the level of protection afforded the preferred freedoms of the Bill of Rights. 